GEOLOGICAL SURVEY CIRCULAR 614

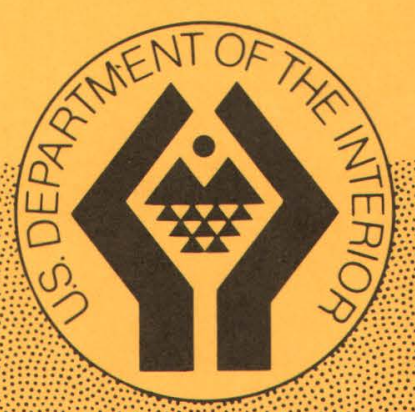

\title{
Metalliferous Deposits
}

Near Granite Mountain

Eastern Seward Peninsula

Alaska 



\section{Metalliferous Deposits}

Near Granite Mountain

Eastern Seward Peninsula

Alaska

By Thomas P. Miller and Raymond L. Elliott

GEOLOGICAL SURVEY CIRCULAR 614

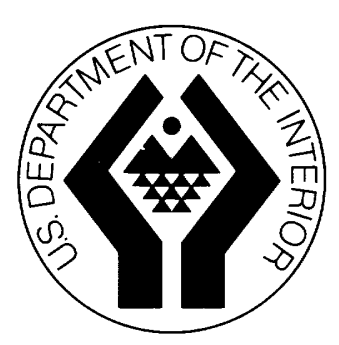


United States Department of the Interior

WALTER J. HICKEL, Secretary

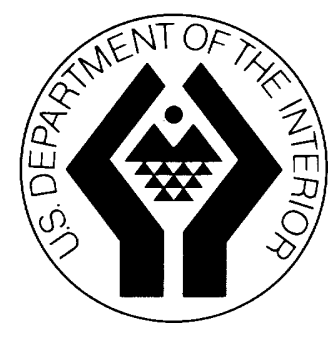

Geological Survey

William T. Pecora, Director

父

Free on application to the U.S. Geological Survey, Washington, D.C. 20242 


\section{CONTENTS}

Abstract

Introduction

Geologic setting

Mineral deposits

Quartz Creek
Page

1 Mineral deposits-Continued

Upper Peace River - 12

Bear Creek

Summary 14

6 References cited _._-_-_-_-_- 14

\section{ILLUSTRATIONS}

FIGURE 1. Geologic map of the Granite Mountain region showing location of areas described in tex ${ }^{4}$.-

2. Geologic map of the Quartz Creek area

3-6. Maps of the Quartz Creek area showing-

3. Lead distribution in stream sediments

4. Zinc distribution in stream sediments

(1)-

5. Copper distribution in stream sediments

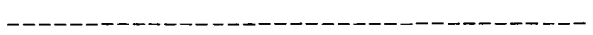

6. Boron distribution in stream sediments

7. Geologic map of the upper Peace River area

8. Map showing location of stream-sediment samples of the upper Peace River area

\section{TABLES}

TABLES 1-2. Analyses of bedrock and soil samples from-

1. Quartz Creek area

2. Upper Peace River area

3. Analyses of stream-sediment samples from the upper Peace River area

4. Analyses of selected grab samples from the Bear Creek prospect 



\title{
METALLIFEROUS DEPOSITS NEAR GRANITE MOUNTAIN EASTERN SEWARD PENINSULA, ALASKA
}

\author{
By Thomas P. Miller and Raymond L. Elliott
}

\begin{abstract}
New deposits of lead, zinc, and silver were found in a large altered zone 18 miles long and 2 to 5 miles wide near Quartz Creek west of Granite Mountain in the eastern Seward Peninsula, Alaska. New deposits of molybdenum, bismuth, and silver were found associated with a previously reported occurrence of uranium, copper, lead, and zinc minerals in the upper Peace River drainage northeast of Granite Mountain. Both groups of deposits are associated spatially with felsic plutonic rocks and occur near the western edge of a late Mesozeic province of volcanic plutonic rocks. Both groups of deposits warrant further investigation as possible exploration target areas.
\end{abstract}

\section{INTRODUCTION}

New deposits of lead, zinc, and silver were found over a large mineralized area near Quartz Creek west of Granite Mountain, in the eastern Seward Peninsula, Alaska, during investigations conducted in 1968 as part of the U.S. Geological Survey's Heavy Metals program. In addition, anomalous concentrations of molybdenum, silver, and bismuth were found in altered syenite and quartz veins in the upper Peace River drainage basin northeast of Granite Mountain at a locality where anomalous amounts of lead, zinc, copper, and uranium have been reported in panned concentrates (Gault and others, 1953). A previously known lead-zinc-gold deposit at Bear Creek (Herreid, 1965) was reexamined and sampled. Placer gold has been mined on a small scale at several localities since the 1900's, and a little platinum has been recovered as a byproduct. The area has not, however, been extensively prospected for other metals.

The deposits occur in the Candle B-5, B-6, C-5, and C-6 quadrangles (mapped at scale of $1: 63,360)$. The closest towns are Candle, 45 miles northeast; Buckland, 40 miles north; and Koyuk, 40 miles south. At Bear Creok a small dirt landing field suitable for light aircraft was in use during the summer of 1968. Another landing strip along the South Fork of Quartz Creek has apparently been unused for many years, but small balloon-tired aircraft may be able to land in the east-west directic $\eta$ (fig. 1). The landing field at the microwave relay station at Granite Mountain itself is restricted and unavailable for civilian use. Most of the area is tundra covered and free of brush except locally along major stream bottoms. The area is one of moderate relief comprised of flattopped mountains and ridges up to 2,800 feet in altitude that form the divide between the Kiwalik and Buckland Rivers.

More than 400 rock, stream-sediment, and soil samples collected during the study of the Granite Mountain region were analyzed by semiquantitative spectrographic and atomicabsorption methods; results wer $\epsilon$ available while fieldwork progressed. A helicopter was used throughout the investigation of the Granite Mountain region-an investigation which lasted about 3 weeks during the summer of 1968.

The authors were ably assisted in the field by Donald H. Grybeck and Richard F. Hardyman, geologic field assistants; Grybeck also assisted in the polished-section study. Semiquantitative spectrographic analyses were done by $\mathrm{K}$. J. Curry, E. E. Martinez, and J. M. Motooka, and atomic-absorption analyses were done by $\mathrm{R}$. L. Miller and W. R. Vaughn. Officials of the Radio Corp. of America and their personnel at the Granite Mountain microwave relay station were very helpful and cooperative. 


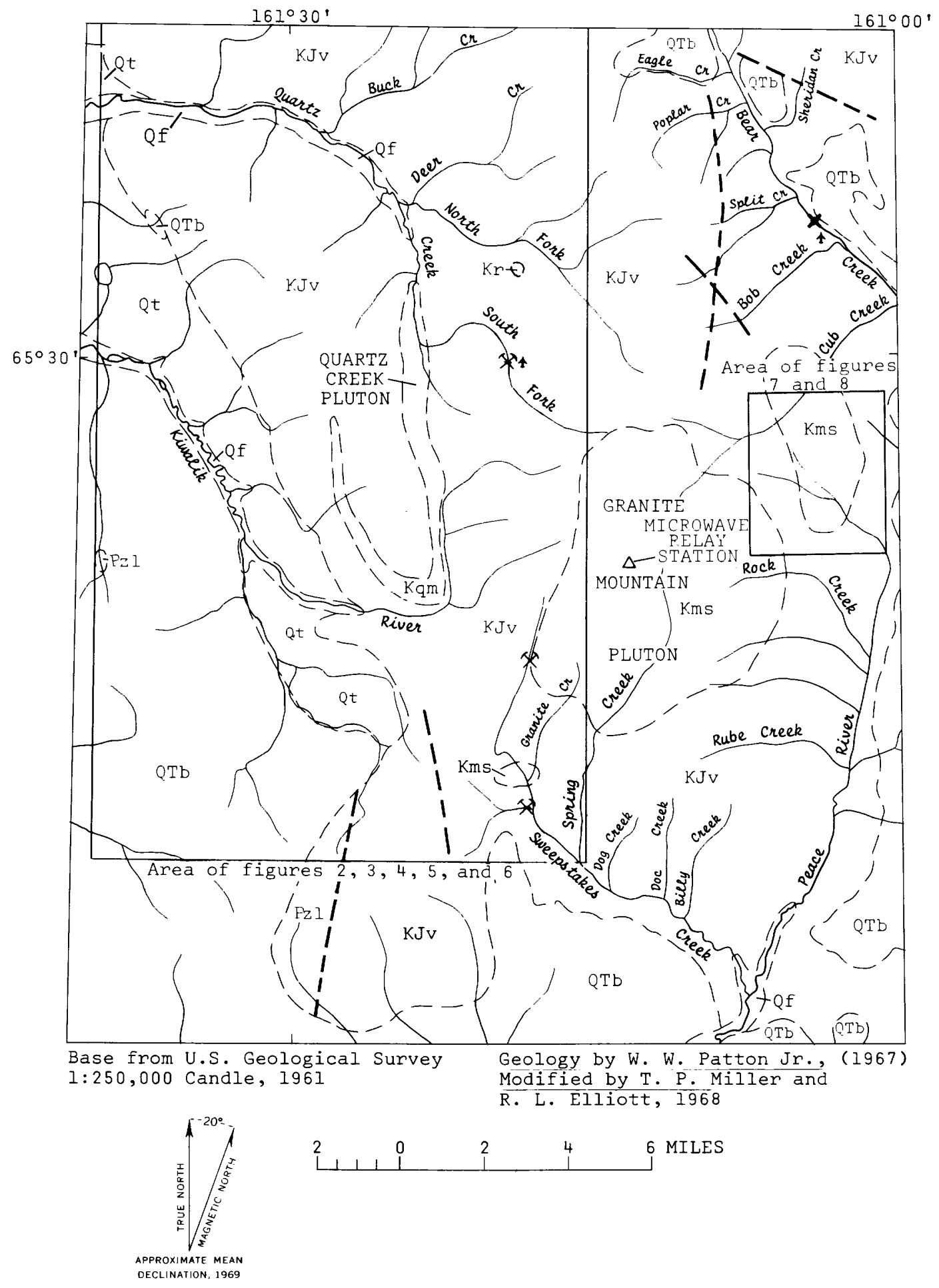

Figure 1.-Geologic map of the Granite Mountain region showing location of areas described in text. 

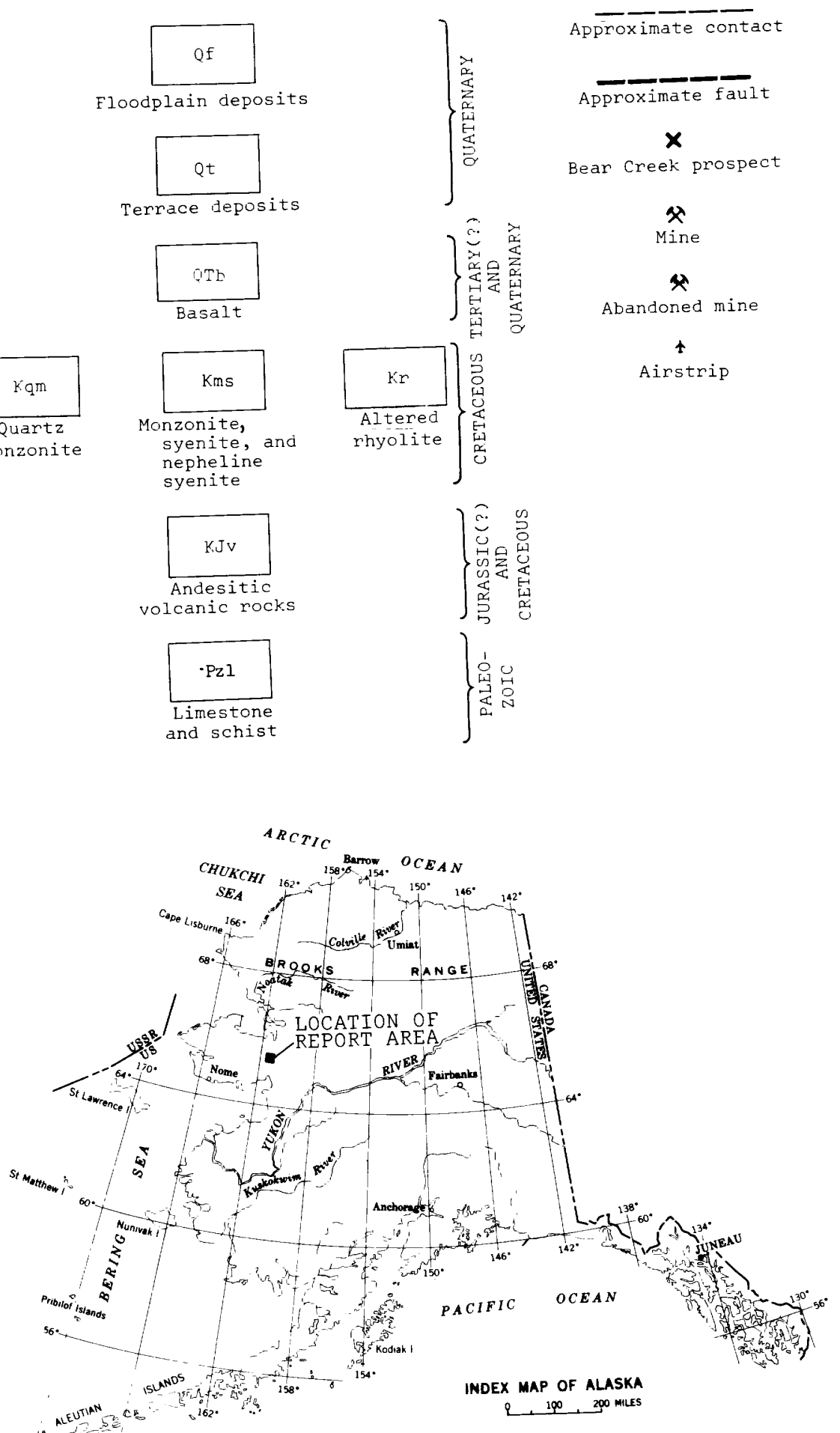

Figure 1.-Continued. 


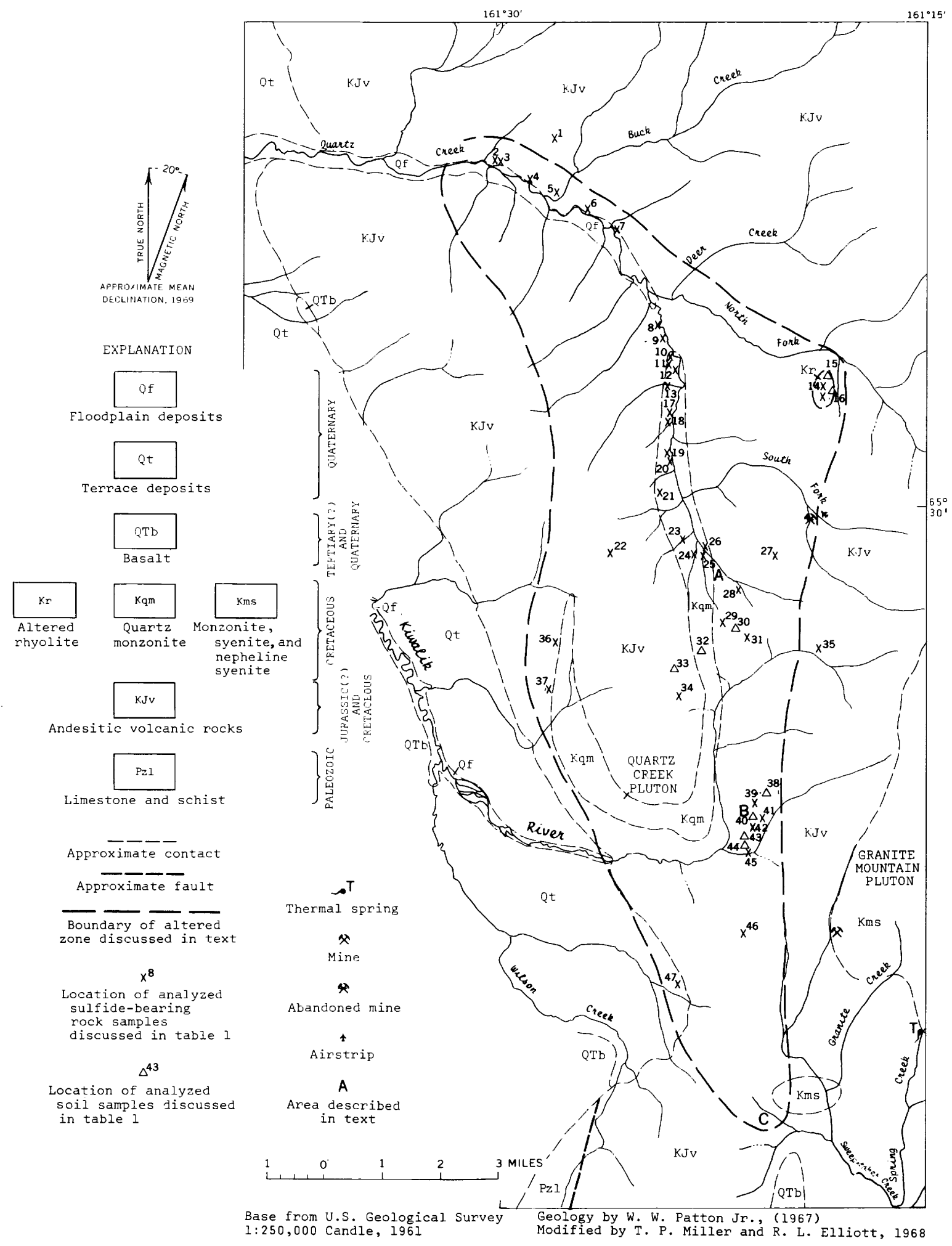

FigURE 2.-Geologic map of the Quartz Creek area. 
The first geological report on the Granite Mountain region was by Moffit (1905) who briefly described the geology of the BucklandKiwalik divide in his report on the gold placers of the Fairhaven district. Smith and Eakin (1911) and Harrington (1919) discussed the gold and platinum placers at Bear and Sweepstakes Creeks. Gault, Killeen, West, and others (1953) found anomalous amounts of uraniumbearing minerals and base-metal sulfides in pan concentrates in the upper Peace River drainage. Herreid (1965) mapped the geology in the vicinity of Bear Creek and took geochemical samples throughout the northern part of the Granite Mountain region. Patton (1967) mapped the regional geology of the Candle quadrangle at a scale of $1: 250,000$.

\section{GEOLOGIC SETTING}

The Granite Mountain region is underlain chiefly by andesitic volcanic rocks of Jurassic(?) and Cretaceous age intruded by felsic plutonic rocks of diverse composition and by small hypabyssal felsic intrusives. Metamorphic rocks of Paleozoic and perhaps Precambrian age lie to the west of the area. Olivine basalt of late Tertiary(?) and Quaternary age occurs in a few low-lying areas and caps some ridges. The mineral deposits in the area are spatially related to the plutonic rocks and occur in both the intrusive rocks and in the surrounding country rocks.

Light-gray massively bedded recrystallized limestone and dolomite with subordinate amounts of mica schist and phyllite crop out only in the southwestern part of the map area (fig. 1). This unit has been tentatively assigned a middle Paleozoic age by Patton (1967) and is the oldest bedrock unit in the Granite Mountain region. It is in fault contact with the Mesozoic volcanic rocks.

The next oldest unit is composed of andesitic and trachyandesitic pyroclastic and volcaniclastic rocks intercalated with andesite flows. The bulk of the unit is thought to be of earliest Cretaceous age on the basis of fossil and radiometric age determinations (Patton, 1967). The andesite near the contact of the various plutons is thermally metamorphosed into rocks of the hornblende hornfels facies, and these grade into rocks of the albite-epidote hornfels facies away from the contact.

The andesitic volcanic rocks were intruded in mid-Cretaceous time by felsic plutonic rocks of diverse composition. The Granite Mountain pluton is the largest intrusive body in the map area. It covers about 30 square miles and is roughly circular in plan. The pluton consists of a complex composed of a core of hornblendepyroxene syenite and monzonite and a border of pseudoleucite syenite, biotite pyroxenite, and various types of garnet-bearing nepheline syenite. It has been assigned a mid-Cretaceous age as a result of a lead-alpha age determination of $100 \pm 15$ m.y. (million years) (Patton, 1967). Satellitic stocks of syenite and neploline syenite occur northeast and south of the pluton. A hook-shaped pluton, herein called the Quartz Creek pluton, of fine-grained biotite-r ornblende quartz monzonite crops out along the upper reaches of the Kiwalik River and Quartz Creek (figs. 1 and 2). The northeastern part of the pluton is extensively altered. All these bodies, though of diverse composition, are tentatively correlated with nearby plutons to the north and northeast that range in composition from quartz monzonite to syenite and monzonite and that include scattered nepheline syenite complexes (Patton and Miller, 1968; Fatton and others, 1968). The plutons in this part of westcentral Alaska have been assigned to the "older" suite of Cretaceous plutonic rocks as a result of several potassium-argon age determinations ranging from 100 to 107 m.y. (Miller and others, 1966).

Fine-grained dikes (not shown in figs. 1 and 2), ranging in composition from latite to trachyte, and dikes of pseudoleucite porphyry cut the andesitic volcanic rocks near the plutons. These dikes are generally less than a few tens of feet thick. The dikes near the Quartz Creek pluton are locally mineralized and contain disseminated pyrite, galena, and sphalerite.

A small body of intensely altered ard oxidized rhyolite intrudes the andesite northwest of Granite Mountain (figs. 1 and 2, maj) unit Kr). The rhyolite is tentatively assignec a Cretaceous age, but its absolute age is unknown. Similar rhyolite bodies to the northeast in the Shungnak quadrangle are assigned an early Late Cretaceous age on the basis of geologic 
relationships and potassium-argon age determinations (Patton and others, 1968).

The youngest rocks in the region are the vesicular olivine basalt flows of late Tertiary (?) and Quaternary age. These flows cover large areas of the Kiwalik River valley and cap some of the ridges north of Bear Creek.

The region has not been glaciated, and thus the valleys are free of glacial drift. Outcrops are sparse owing to the extensive frost riving which has reduced most of the exposures to rubble.

The Granite Mountain region is located near the west edge of a late Mesozoic province of andesitic volcanic rocks and felsic plutonic intrusives. Rocks of this volcanic-plutonic province crop out over much of west-central Alaska and the easternmost Seward Peninsula. The central and western Seward Peninsula consists of a thrust-faulted province of metamorphic and sedimentary rocks of Paleozoic age (some of these rocks are perhaps as old as Precambrian) cut by intrusive bodies of various compositions. and ages. A north-south boundary separates these two provinces. This boundary is concealed over much of its length by Quaternary flows, but wherever Mesozoic volcanic rocks can be observed in juxtaposition with older rocks, the contact is a faulted one. This boundary between two provinces so different in lithology, age, and tectonic history may be a fault over its entire length.

\section{MINERAL DEPOSITS}

The known mineral occurrences of the Granite Mountain region include lead, zinc, and silver deposits in the Quartz Creek area; a molybdenum, bismuth, silver, copper, lead, and uranium deposit in the upper Peace River drainage; and a lead, zinc, and gold deposit at Bear Creek. The relationships among the individual deposits are unknown, and there are differences in mineralogy, chemistry, and lithology. All the deposits, however, are related spatially to felsic plutonic rocks.

Each of the deposits is described in the following sections of the report, and geologic maps of the Quartz Creek and upper Peace River areas are included. Geochemical maps showing the distribution of lead, zinc, copper, and boron in stream sediments from the Quartz Creek and upper Kiwalik River drainage basins are included. These elements were determined by semiquantitative spectrographic analyses in which the results are reported to the nearest number in the series $1,0.7,0.5,0.3,0.2,0.15$, 0.1 , and so forth. Stream-sediment values of $70 \mathrm{ppm}$ (parts per million) or greater for lead and boron, $100 \mathrm{ppm}$ or greater for copper, and $10 \mathrm{ppm}$ or greater for molybdenur are considered anomalous. Because of the high limit of detection for zinc $(200 \mathrm{ppm})$, even detectable zinc is considered anomalous. The solection of these limits is subjective and interpretive on the part of the authors; they are. however, based on the distribution of elements in several hundred stream-sediment samples collected from this geologic province over a period of several years.

Semiquantitative spectrographic and atomicabsorption analyses of mineralized ro?k samples are shown in tables 1, 2, and 4. Anomalous limits for bedrock samples are difficult to determine, because many of the rock samples are so altered that it is impossible to identify the original rock or mineral. For this reason, limits have been arbitrarily selected for each element. These limits, which are thought to be above what is generally considered background for the various rock types found in the Granite Mountain region, are given at the bottom of each table as are the limits of detection of the analytical technique.

\section{QUARTZ CREEK}

Numerous occurrences of argentiferous galena, sphalerite, pyrite, and arsenopyrite have been found in an altered zone about 18 miles long and 2 to 5 miles wide west of Granite Mountain (fig. 2). This zone exten $\mathrm{Ns}$ N. $15^{\circ}$ W. across the drainage basins of the upper Kiwalik River and Quartz Creek and is roughly parallel to prominent lineaments in the area. Conspicuous reddish-orange oxidized areas and large buff carbonate replacement boties occur in the andesite and in the quartz monzonite that underlies this zone. A striking feature of the mineralized rock in this zone is tr $\because$ association of sulfides with tourmaline.

Semiquantitative spectrographic analyses of sulfide-bearing material from this zone (table 1) show, in addition to the high lead, zinc, arsenic, and silver contents, consistently high 
boron contents which indicate the abundance of tourmaline. The manganese and scandium content is also high. Copper and antimony, though present in anomalous amounts in many samples, never exceed 2,000 and $700 \mathrm{ppm}$, respectively. Gold is low, less than $1 \mathrm{ppm}$, even though arsenic is high. Tin occurs in about 50 percent of the analyzed samples in amounts ranging from just detectable to $500 \mathrm{ppm}$. Many of these chemical characteristics are similar to those described by Sainsbury and Hamilton (1967) as being typical of lode tin deposits. The sulfide mineral suite and the abundance of tourmaline are also similar to the mineral assemblage of the western Seward Peninsula tin district (Sainsbury, 1964).

Many stream-sediment samples from this zone contain very anomalous amounts of lead, zinc, copper, and boron (figs. 3-6). Silver is reported in many of the samples but is never more than $0.7 \mathrm{ppm}$. Arsenic is reported in some samples, particularly near the head of the easternmost creek in area $A$ where values as high as $2,000 \mathrm{ppm}$ occur. Sediment samples from streams draining area $\mathrm{A}$ contain as much as $1,000 \mathrm{ppm}$ lead and $1,500 \mathrm{ppm}$ zinc (figs. 3 and 4), in addition to anomalous boron and copper. Sediment in streams from area C contains anomalous zinc values ranging from 300 to $1,500 \mathrm{ppm}$ (fig. 4). This low area is completely covered with tundra, and the source of the anomaly was not found. Anomalous concentrations of lead, zinc, arsenic, silver, and boron were found in soil and rock samples from the ridge in area $B$ in the upper Kiwalik River drainage (fig. 2). Stream sediments west of this ridge (figs. 3 and 4) show anomalous lead and zinc. A copper anomaly occurs in the stream sediments of the northern part of the Quartz Creek drainage basin. The higher copper content generally coincides with lower lead and zinc values and suggests lateral zonation in the major altered zone. The eastern edge of the copper anomaly begins in the North Fork of Quartz Creek near a small body of intensely oxidized rhyolite (map unit $\mathrm{Kr}$, fig. 2; fig. 5), and composite grab and soil samples of the rhyolite (samples 14, 15, and 16 in table 1) show anomalous concentrations of copper, antimony, and boron. The copper anomaly persists in the stream sediments of Quartz Creek all the way to the Kiwalik River Valley (fig. 2).

The largest area of sulfidized rock within this altered zone is in area A in and around hydrothermally altered quartz monzonite of the Quartz Creek pluton (fig. 2). The presence of sulfide-tourmaline-quartz-carbonate foat in all the streams draining this tundra-covered area and the location of lode occurrences of sulfide minerals and of anomalous stream-sediment and soil samples (fig. 2; table 1) outline a strongly mineralized area of about 6 square miles extending from the ridge at the headwaters of the streams draining area $\mathrm{A}$ to about a mile north of their junction with the South Fork of Quartz Creek.

The principal sulfide minerals in area $\mathrm{A}$ are galena, sphalerite, pyrite, and arsenopyrite. Realgar and orpiment were found on fracture surfaces at locality 28 (fig. 2), and cralcopyrite occurs as small blebs generally associated with sphalerite and visible only in polished section. The intrusive rock in this area appears to have been tourmalinized along closely spaced fractures and (or) joints. Where the tourmaline, a black to green variety, first replaced the mafic minerals, a "bleached" quartz-feldspar-tourmaline rock resulted. Where tourmalinization was complete, a dense fine-grained black rock composed entirely of quartz and tourmaline was formed. Sericitization has also taken place, and where the feldspars were not replaced by tourmaline, they were sericitized. Late carbonate veins and replacement bodies cut the altered quartz monzonite. The anderite in this area is also pervasively altered, and scapolite is common as thin veinlets and as pseudomorphs after feldspar. The sulfide minerals occur in both the altered tourmalinized rock and in the carbonate veins as disseminated grains, masses, and aggregates of grains. The poor exposures and extensive frost riving prohibit determination of the thickness and attitude of the sulfide-bearing material. However, at locality 25 (fig. 2), a strongly mineralized aggregate of quartz, tourmaline, cark mate, and sulfide minerals crops out for about 50 feet in the streambed and cutbank. A composite grab sample (sample 25B, table 1 ) shows over 2 percent lead, 4 percent zinc, and $1 \frac{1}{2}$ ounce per ton silver. 


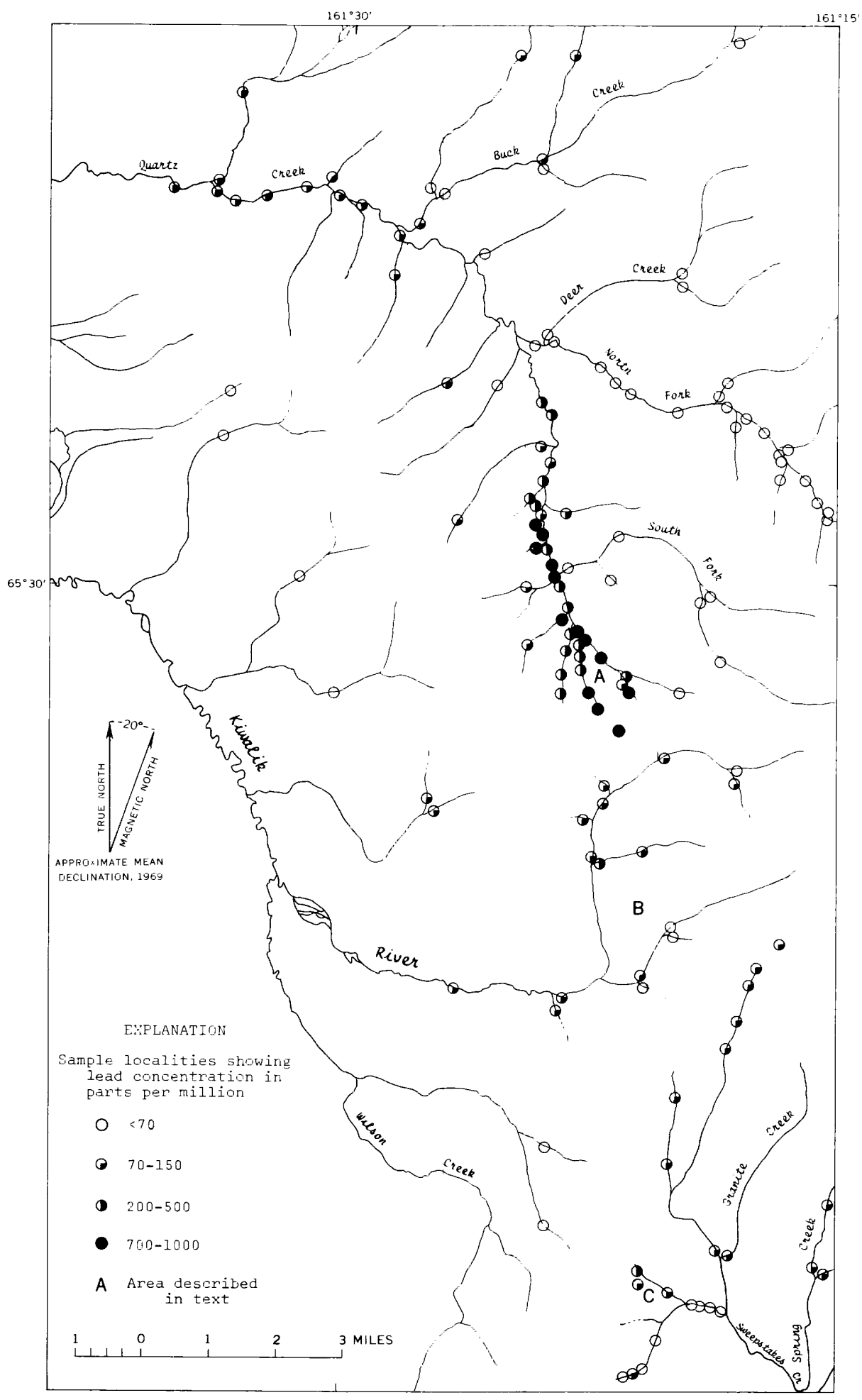

FIGURE 3.-Lead distribution in stream sediments of the Quartz Creek area. 


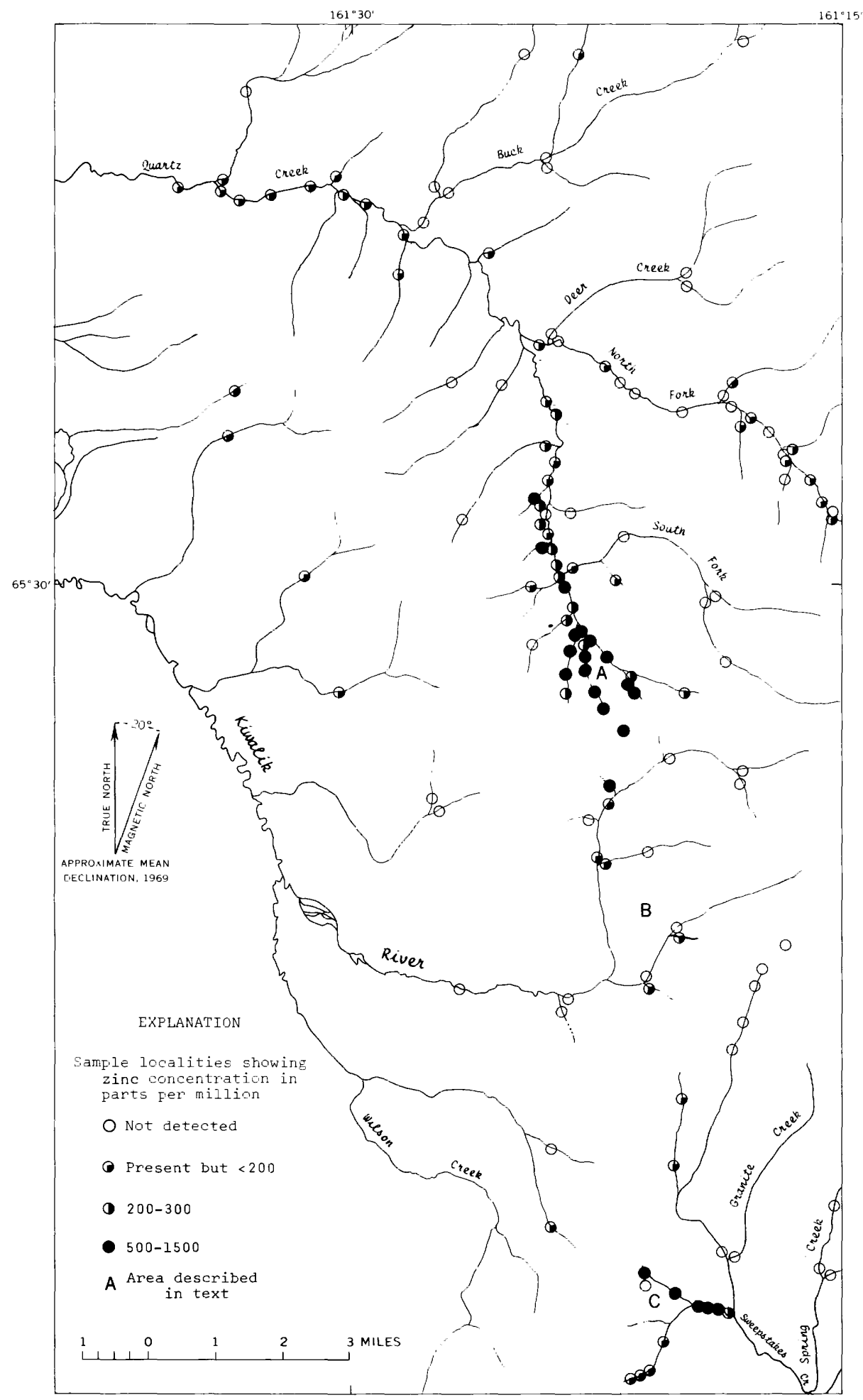

FIGURE 4.-Zinc distribution in stream sediments of the Quartz Creek area. 


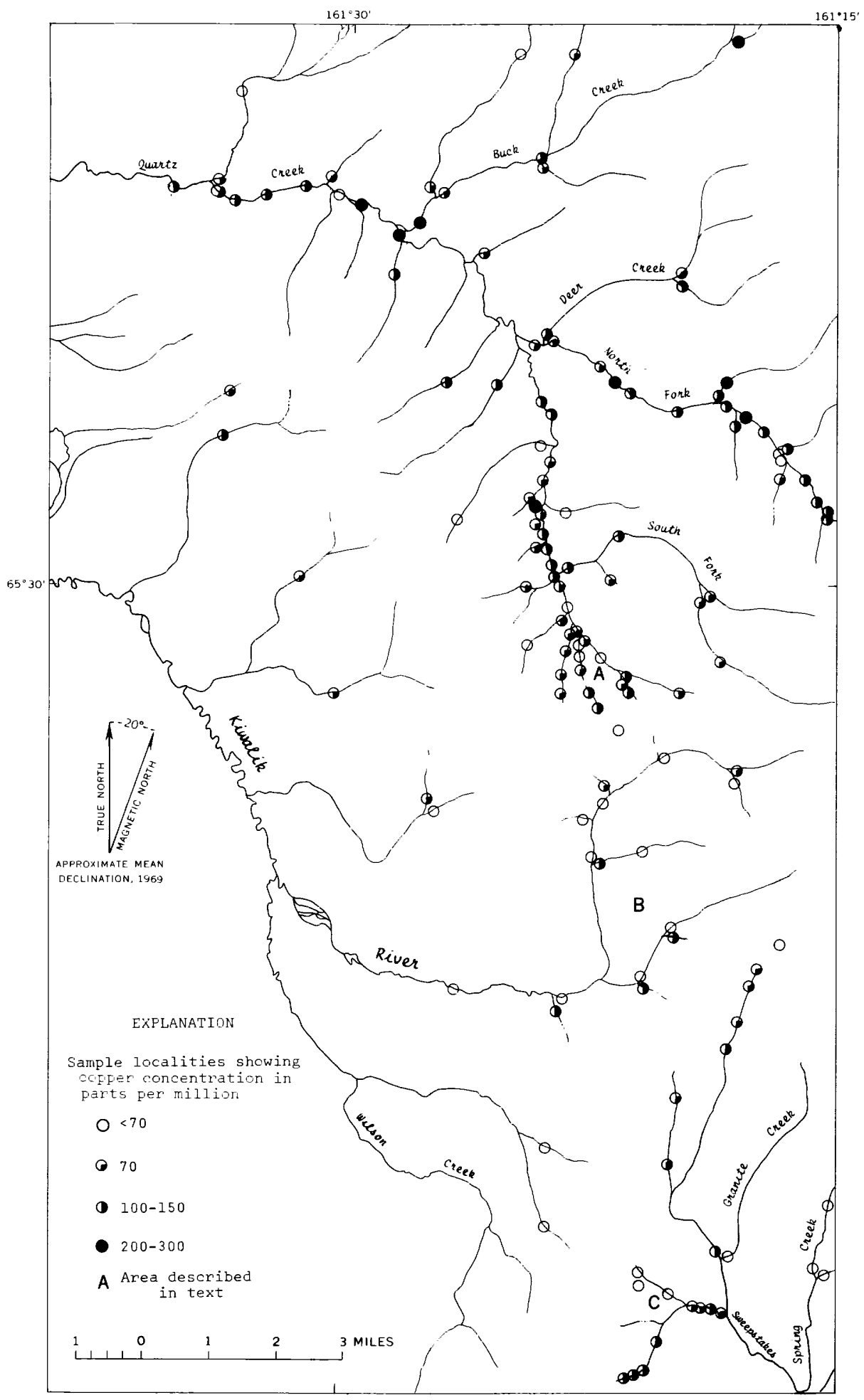

FIGURE 5.-Copper distribution in stream sediments of the Quartz Creek area. 


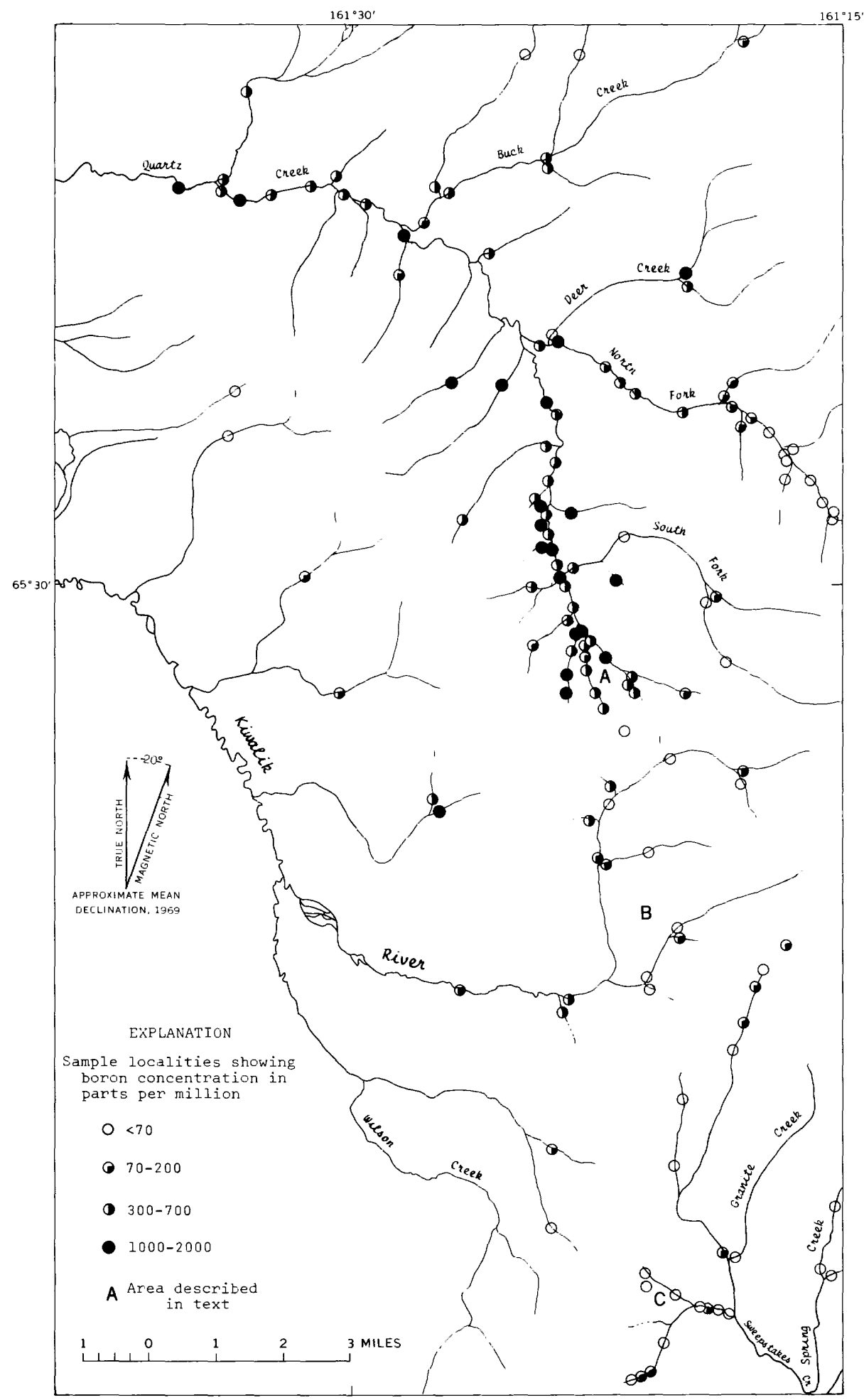

FigURE 6.-Boron distribution in stream sediments of the Quartz Creek area. 
The hooked shape of the Quartz Creek pluton suggests the exposed roof of an otherwise concealed pluton. If so, the strongly mineralized zone described here may be only part of a larger zone along the roof of this pluton. Widespread mineralization is also indicated in the andesite away from the Quartz Creek pluton throughout the 18-mile-long altered zone, as shown by the many occurrences of galena, sphalerite, arsenopyrite, and pyrite. These sulfides occur with tourmaline as disseminated grains in oxidized carbonate veins and replacement bodies. Other occurrences of sulfide minerals undoubtedly exist in oxidized areas that were not examined but are common throughout the large altered zone. The original sulfides have been completely oxidized in many cases, but analyses of oxidized rock and soil show anomalous lead, zinc, silver, arsenic, and boron. Scheelite was found in pyrite-tourmaline-quartz vein material in frost-riven rubble at locality 36 (fig. 2) and a composite grab sample of this material (sample 36, table 1) contained more than $10,000 \mathrm{ppm}$ tungsten.

The age of the mineralization is not known. Both the Quartz Creek quartz monzonite and the small rhyolite body (map unit $\mathrm{Kr}$ ) are mineralized, but their mutual relationship is uncertain. The 18-mile-long altered zone is roughly centered around the east limb of the hookshaped Quartz Creek pluton, and the strong mineralization in area $A$ occurs chiefly in the quartz monzonite of the pluton. These observations suggest that the mineralization is genetically related to the quartz monzonite. A possible structural control of mineralization is suggested by the rough parallelism of the trend of the 18-mile-long altered zone and prominent lineaments in the area.

All these factors make this large 18-milelong altered zone worth further investigation as a possible exploration target. Trenching and stripping in area $\mathrm{A}$ would help define the extent and potential of the large area of mineralized rock there. Soil sampling and perhaps the use of reconnaissance electrical geophysical methods over much of the upper Kiwalik River and Quartz Creek drainage basins might locate mineralized areas in the andesite and indicate good drilling locations. Drilling would certainly be necessary to determine the extent of mineralization in the altered metalliferous rhyolite (map unit $\mathrm{Kr}$ ).

\section{UPPER PEACE RIVER}

Anomalously high concentrations of molybdenum, bismuth, silver, copper, and lead are found in the soils, stream sediments, and outcrops of the upper Peace River drainage basin (figs. 7 and 8). These anomalous metal concentrations occur over an area of about 2 square miles centered around the two main forks of the Peace River. The area is low and tundra covered except for a few scattered outcrops and frost-riven rubble along the cutbanks of the creeks.

The area is underlain by a smell satellitic stock of the Granite Mountain pluton. The stock is composed of several varieties of syenite - the most common being a pinl. mediumgrained, hornblende-biotite variety. A pink, fine- to medium-grained, porphyritic syenite composed of over 90 percent perthitic feldspar and less than 1 percent mafic minerals is also common. Garnet-bearing nepheline syenite crops out on the south side of the ridge between the northern fork of the Peace River and Cub Creek and garnet-bearing nepheline syenite float is common in both forks.

Locally the syenite contains abundant disseminated pyrite cubes, a little visible finegrained molybdenite, and abundant accessory magnetite and purple fluorite. Composite grab samples of syenite taken over areas ranging from 10 to 100 square feet contain 15 to 200 ppm molybdenum (samples 2, 3, 6, 8-13, and 15 in table 2) as well as anomalously high amounts of bismuth, silver, and copper. Rubble of pyrite-quartz material is also aburdant along the cutbanks of both forks; composite grab samples of this material contain from a trace to more than $2,000 \mathrm{ppm}$ molybdenum as well as anomalously high bismuth, silver, end copper (samples 4, 5, 7, and 14 in table 2). A canary yellow alteration product, abundart in both syenite and vein material, has beer identified as ferromolybdite from X-ray diffraction patterns. Where the syenite is cut by pyrite-quartz veins, the syenite is bleached and ox tized, and it contains disseminated pyrite and, less commonly, molybdenite.

In soils from the banks of the northern fork, molybdenum contents reach as high as $70 \mathrm{ppm}$ 

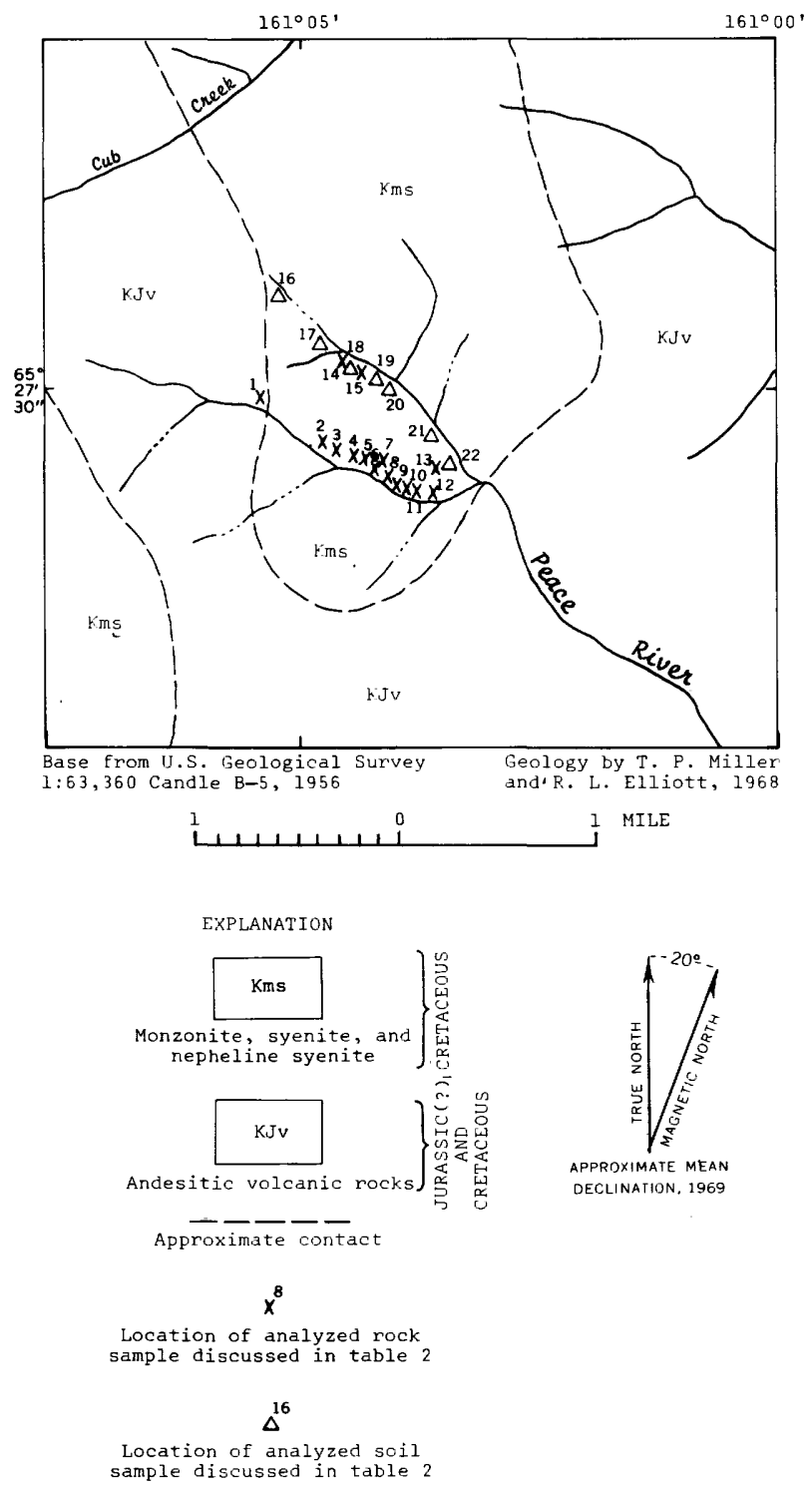

FigURE 7.-Geologic map of the upper Peace River area.

(samples 16-22 in fig. 7 and table 2) ; and in stream sediments from this fork and its tributaries, as high as $30 \mathrm{ppm}$ (samples 3-11 in fig. 8 and table 3). Copper and lead contents are also anomalously high in the stream-sediment samples from this area (fig. 8; table 3); however, the highest contents of copper and lead are in the upper parts of southern and northern forks respectively, whereas the highest molybdenum contents are from the lower part of the northern fork.

Pan concentrates collected from this area by the U.S. Geological Survey in 1951 and 1952
(Gault and others, 1953) in a search for uranium, showed anomalously high concentrations of uranothorianite as well as a variety of other metallic minerals such as galena, cralcopyrite, bornite, tetradymite, sphalerite, pyrite (up to 50 percent of the concentrate), and pyrrhotite. Intergrowths of galena, sphalerite, chalcopyrite, pyrite, and gummite (probably a decomposition product of uranothorianite) were observed in some mineral grains (Gault and others, 1953, p. 29). The source of the uranothorianite and associated sulfide: was not found during the 1951-52 investigations, although West (in Gault and others, 1953, p. 29-30) suggested a lode deposit at the head of the Peace River. The present study shows that the syenite and associated quartz veins exposed near the junction of the two main forks both contain anomalous amounts of molybdenum, bismuth, silver, copper, and lead. These deposits, and probably similar ones upstream, are the most likely source of the sulfides and uranothorianite found in the pan concentrates. The association of uranium, silvar, molybdenum, bismuth, copper, and lead seen here is typical of many uranium-bearing veins elsewhere in the United States (Walker and Adams, 1963).

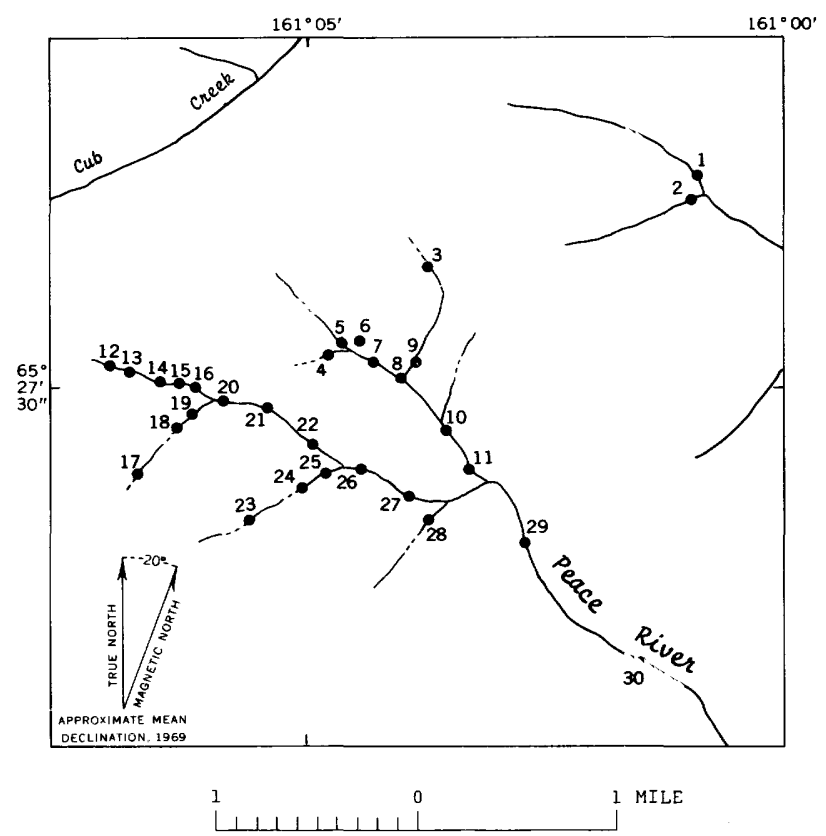

FIGURE 8.-Location of stream-sediment semples of the upper Peace River area. 
The relationship, if any, between the deposits of lead, zinc, and silver at Quartz Creek and the deposits in the upper Peace River drainage is unknown. The absence of tourmaline and arsenopyrite (and therefore low boron and arsenic content), the low tin content, and the presence of abundant fluorite in the upper Peace River deposits suggests that the two deposits are not genetically related.

Because of the very poor exposures and short time spent in this investigation, it is not possible to give a complete evaluation of the potential of this area. However, a considerable area of high concentrations of a wide variety of metals has been outlined and is thought to be worthy of further exploration. A trenching and stripping program near the junction of the two main forks of the Peace River and also in their headwaters would help define the extent and amount of mineralized rock. Drilling may be necessary in areas with a thick overburden.

\section{BEAR CREEK}

Galena, sphalerite, and pyrite have been reported in andesite at the north end of the airstrip on Bear Creek north of the Granite Mountain pluton (fig. 1). The sulfides occur in quartz-calcite veinlets and as disseminated grains in the andesite near a mafic syenite dike (Herreid, 1965). The mineralized zone is about 200 feet wide and trends northwest. Gold can be panned from the limonitic capping over the mineralized rock. Stream-sediment samples downstream from the mineralized zone show a lead-zinc-copper anomaly extending for about a mile. Soil samples from a drainage ditch above the deposit contain anomalous lead and zinc and are thought by Herreid to indicate additional mineralization in the area. Placer gold has been mined on Bear Creek, particularly downstream from the mineralized area, off and on for over 60 years.

The deposit was reexamined during the present investigation. Little can be added to Herreid's account except that polished-section study shows that arsenopyrite, bournonite, and a little gold are also present in the sulfide aggregate. Analyses of mineralized rock samples are given in table 4 and show anomalous lead, zinc, silver, arsenic, cadmium, gold, copper, and antimony.

The mafic syenite dike described by Herreid appears to be a biotite pyroxenite containing potassium feldspar and is similar to pyroxenite occurring along the edge of the Granite Mountain pluton.

The Bear Creek deposit is not well enough exposed to evaluate its potential at the present time. However, the deposit is of interest because of the mineralogical and chemical differences between it and the Quartz Creek deposit. The lead-zinc deposit at Bear Creek occurs entirely in andesite and has anomalously high antimony (samples 2-6, table 4) and gold, whereas boron and tin are quite low in direct contrast to the high boron and anomalous tin in the Quartz Creek lead-zinc deposit. Thus, a different origin for the two deposits is suggested.

\section{SUMMARY}

Investigation of the Granite Mountain area located two new mineralized areas thought to be worth further exploration. Both areas are related, at least spatially, to felsic plutonic rocks. The deposits in the Quartz Creek area are scattered over an 18-mile-long zone roughly parallel to prominent lineaments in the area and centered around an altered quartz monzonite. The deposits in the upper Peace River drainage are disseminated in a syenitic stock satellitic to the Granite Mountain rluton and cut by mineralized quartz veins. Studies of stream-sediment samples in this area indicate anomalous metal contents over an area of about 2 square miles. More detailed surface prospecting together with geochemical and geophysical surveys, trenching, and drilling will be necessary to determine the extent and $\varepsilon$ mount of mineralized rock.

\section{REFERENCES CITED}

Gault, H. R., Killeen, P. L., West, W. S., and others, 1953, Reconnaissance for radioactive deposits in the northeastern part of the Seward Peninsula, Alaska, 1945-47 and 1951: U.S. Geol. Survey Circ. $250,31 \mathrm{p}$.

Harrington, G. L., 1919, Mineral resources of Alaska, report on progress of investigations in 1917: U.S. Geol. Survey Bull. 692, p. 353-408. 
Herreid, Gordon, 1965, Geology of the Bear Creek area, Seward Peninsula, Candle quadrangle, Alaska: Alaska Div. Mines and Minerals Rept. 12, 16 p.

Miller, T. P., Patton, W. W., Jr., and Lanphere, M. A., 1966, Preliminary report on a plutonic belt in west-central Alaska, in Geological Survey research 1966: U.S. Geol. Survey Prof. Paper 550-D, p. D158-D162.

Moffit, F. H., 1905, The Fairhaven gold placers, Seward Peninsula, Alaska: U.S. Geol. Survey Bull. 247, $85 \mathrm{p}$.

Patton, W. W., Jr., 1967, Regional geologic map of the Candle quadrangle, Alaska: U.S. Geol. Survey Misc. Geol. Inv. Map I-492, scale $1: 250,000$.

Patton, W. W., Jr., and Miller, T. P., 1968, Regional geologic map of the Selawik and southeastern Baird Mountain quadrangles, Alaska: U.S. Geol. Survey Misc. Geol. Inv. Map I-530, scale $1: 250,000$.
Patton, W. W., Jr., Miller, T. P., and Tailleur, I. L., 1968, Regional geologic map of the Shurgnak and southern part of the Ambler River quadrangles, Alaska: U.S. Geol. Survey Misc. Geol. Inv. Map I-554, scale 1:250,000.

Sainsbury, C. L., 1964, Geology of the Lost $F^{\text {iver mine }}$ area, Alaska: U.S. Geol. Survey Bull. 1129, 80 p.

Sainsbury, C. L., and Hamilton, J. C., 1967, Geology of lode tin deposits: Internat. Tin Council, 35 p.

Smith, P. S., and Eakin, H. M., 1911, A geologic reconnaissance in southeastern Seward Peninsula and the Norton Bay-Nulato region, Alaska: U.S. Geol. Survey Bull. 449, 146 p.

Walker, G. W., and Adams, J. W., 1963, Mineralogy, internal structure and textural characteristics, and paragenesis of uranium-bearing veins in the conterminous United States: U.S. Geol. Survey Prof. Paper 455-D, p. 55-90. 


\begin{tabular}{|c|c|c|c|c|c|c|c|c|c|c|c|}
\hline $\begin{array}{l}\text { Sample } \\
\text { locality }\end{array}$ & eld & Ag & As & $\mathrm{Au}$ & B & $\mathbf{B a}$ & $\mathbf{B i}$ & $\mathrm{Cd}$ & Co & $\mathrm{Cr}$ & $\mathrm{Cu}$ \\
\hline 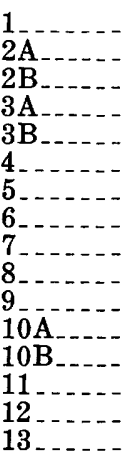 & $\begin{array}{r}68 \mathrm{AMm} 236 \mathrm{~A} \\
235 \mathrm{~A} \\
235 \mathrm{~B} \\
68 \mathrm{AEr} 124 \mathrm{~A} \\
124 \mathrm{~B} \\
68 \mathrm{AGk} 82 \\
80 \\
68 \mathrm{AMm} 372 \\
373 \mathrm{~A} \\
68 \mathrm{AGk} 44 \mathrm{~A} \\
43 \\
41 \\
40 \\
38 \\
37 \\
36\end{array}$ & $\begin{array}{r}\mathrm{L} \\
.5 \\
\mathrm{~L} \\
1.5 \\
20 \\
\mathrm{~N} \\
\mathrm{~N} \\
.5 \\
\mathrm{~L} \\
.7 \\
\mathrm{~L} \\
\mathrm{~N} \\
\mathrm{~L} \\
7 \\
7 \\
\mathrm{~N}\end{array}$ & $\begin{array}{r}\mathrm{L} \\
500 \\
{ }^{*} \mathrm{G}(10,000) \\
\mathrm{N} \\
\mathrm{N} \\
3,000 \\
\mathrm{~N} \\
\mathrm{~L} \\
\mathrm{~L} \\
300 \\
\mathrm{~L} \\
500 \\
1,500 \\
{ }^{*} \mathrm{G}(10,000) \\
{ }^{*} \mathrm{G}(10,000) \\
10,000\end{array}$ & $\begin{array}{l}\mathrm{N} \\
\mathrm{N} \\
.06 \\
\mathrm{~N} \\
\mathrm{~N} \\
\mathrm{~N} \\
2 \\
\mathbf{N} \\
\mathrm{N} \\
\mathrm{N} \\
\mathrm{N} \\
\mathrm{N} \\
\mathrm{N} \\
.1 \\
\mathrm{~N} \\
\mathrm{~N}\end{array}$ & $\begin{array}{c}\mathrm{G}(2,000) \\
2,000 \\
\mathrm{G}(2,000) \\
* \mathrm{G}(2,000) \\
*^{*}(2,000) \\
\mathrm{G}(2,000) \\
\mathrm{G}(2,000) \\
{ }^{*}, 150 \\
{ }^{*} \mathrm{G}(2,000) \\
{ }^{*} \mathrm{G}(2,000) \\
\mathrm{G}(2,000) \\
*^{\mathrm{G}}(2,000) \\
*^{\mathrm{G}}(2,000) \\
{ }^{*} \mathrm{G}(2,000) \\
{ }^{*} \mathrm{G}(2,000) \\
{ }^{*} \mathrm{G}(2,000)\end{array}$ & $\begin{array}{r}300 \\
500 \\
150 \\
70 \\
150 \\
500 \\
3,000 \\
200 \\
\mathrm{~L} \\
100 \\
50 \\
70 \\
100 \\
\mathrm{~L} \\
\mathrm{~L} \\
\mathrm{~L}\end{array}$ & $\begin{array}{l}N \\
N \\
20 \\
N \\
N \\
L \\
N \\
N \\
N \\
N \\
N \\
N \\
N \\
N \\
N \\
N\end{array}$ & $\begin{array}{r}N \\
N \\
N \\
100 \\
150 \\
N \\
N \\
N \\
N \\
N \\
N \\
N \\
N \\
N \\
N \\
N\end{array}$ & $\begin{array}{r}20 \\
30 \\
300 \\
10 \\
20 \\
20 \\
15 \\
150 \\
20 \\
5 \\
150 \\
15 \\
100 \\
500 \\
10 \\
100\end{array}$ & $\begin{array}{r}15 \\
20 \\
15 \\
15 \\
15 \\
20 \\
\mathrm{~L} \\
70 \\
70 \\
70 \\
20 \\
700 \\
500 \\
70 \\
300 \\
150\end{array}$ & $\begin{array}{r}200 \\
70 \\
100 \\
300 \\
300 \\
70 \\
70 \\
150 \\
150 \\
70 \\
700 \\
200 \\
150 \\
300 \\
150 \\
15\end{array}$ \\
\hline $\begin{array}{l}14 \mathrm{~A}-\ldots- \\
14 \mathrm{~B}-\ldots- \\
14 \mathrm{C}-\ldots- \\
15 \ldots \ldots \\
16 \ldots-\ldots \\
17 \ldots \ldots\end{array}$ & $\begin{array}{r}68 \mathrm{AMm} 240 \\
360 \mathrm{~A} \\
360 \mathrm{~B} \\
68 \mathrm{AEr} 126 \\
125 \\
68 \mathrm{AGk} 34\end{array}$ & $\begin{array}{r}\mathbf{N} \\
\mathbf{N} \\
\mathbf{N} \\
\mathrm{N} \\
\mathrm{L} \\
1.5\end{array}$ & $\begin{array}{r}\mathrm{N} \\
\mathrm{L} \\
\mathrm{N} \\
\mathrm{N} \\
\mathrm{N} \\
\mathrm{G}(10,000)\end{array}$ & $\begin{array}{l}\mathbf{N} \\
\mathbf{N} \\
\mathbf{N} \\
\mathbf{N} \\
\mathbf{N} \\
\mathbf{N}\end{array}$ & $\begin{array}{r}1,000 \\
30 \\
50 \\
300 \\
300 \\
*^{G}(2,000)\end{array}$ & $\begin{array}{r}1,500 \\
700 \\
1,500 \\
1,500 \\
1,500 \\
150\end{array}$ & $\begin{array}{l}\mathbf{N} \\
\mathbf{N} \\
\mathbf{L} \\
\mathbf{N} \\
\mathbf{N} \\
\mathbf{N}\end{array}$ & $\begin{array}{l}\mathbf{N} \\
\mathbf{N} \\
\mathbf{N} \\
\mathbf{N} \\
\mathbf{N} \\
\mathbf{N}\end{array}$ & $\begin{array}{l}10 \\
15 \\
\mathrm{~L} \\
10 \\
10 \\
10\end{array}$ & $\begin{array}{r}70 \\
70 \\
20 \\
100 \\
70 \\
15\end{array}$ & $\begin{array}{r}500 \\
150 \\
150 \\
150 \\
100 \\
70\end{array}$ \\
\hline 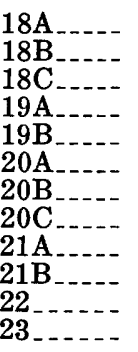 & $\begin{array}{c}68 \mathrm{AMm} 212 \mathrm{~A} \\
212 \mathrm{~B} \\
68 \mathrm{AEr} 116 \\
68 \mathrm{AGk} 31 \mathrm{~A} \\
31 \mathrm{~B} \\
29 \\
68 \mathrm{AMm} 213 \mathrm{~B} \\
213 \mathrm{C} \\
210 \mathrm{~A} \\
210 \mathrm{C} \\
370 \\
68 \mathrm{AGk} 52\end{array}$ & $\begin{array}{r}1 \\
\mathrm{~N} \\
50 \\
200 \\
150 \\
7 \\
30 \\
7 \\
100 \\
150 \\
20 \\
2\end{array}$ & $\begin{array}{r}\mathrm{N} \\
5,000 \\
\mathrm{~N} \\
700 \\
3,000 \\
\mathrm{~N} \\
\mathrm{~N} \\
\mathrm{~N} \\
5,000 \\
\mathrm{~L} \\
\mathrm{~N} \\
\mathrm{~N}\end{array}$ & $\begin{array}{l}\mathrm{N} \\
\mathrm{N} \\
\mathrm{N} \\
.06 \\
.2 \\
\mathrm{~N} \\
\mathrm{~N} \\
\mathrm{~N} \\
\mathrm{~N} \\
\mathrm{~N} \\
\mathrm{~N} \\
\mathrm{~N}\end{array}$ & $\begin{array}{r}15 \\
1,500 \\
300 \\
\mathrm{G}(2,000) \\
{ }^{*} \mathrm{G}(2,000) \\
{ }^{*} \mathrm{G}(2,000) \\
*^{*} \mathrm{G}(2,000) \\
{ }^{*} \mathrm{G}(20,000) \\
30 \\
30 \\
10 \\
30\end{array}$ & $\begin{array}{r}150 \\
1,500 \\
300 \\
300 \\
70 \\
150 \\
\mathrm{~L} \\
\mathrm{~L} \\
\mathrm{~L} \\
70 \\
300 \\
\mathrm{~L}\end{array}$ & $\begin{array}{l}\mathbf{N} \\
\mathrm{N} \\
\mathrm{N} \\
\mathrm{N} \\
\mathrm{N} \\
\mathrm{N} \\
\mathrm{N} \\
\mathrm{N} \\
70 \\
\mathrm{~L} \\
\mathrm{~L} \\
\mathrm{~N}\end{array}$ & $\begin{array}{r}\mathrm{N} \\
\mathrm{N} \\
\mathrm{G}(500) \\
150 \\
300 \\
50 \\
100 \\
\mathrm{~N} \\
\mathrm{~N} \\
\mathrm{~N} \\
\mathrm{~N} \\
\mathrm{~L}\end{array}$ & $\begin{array}{r}\mathrm{N} \\
15 \\
50 \\
50 \\
100 \\
\mathrm{~L} \\
\mathrm{~L} \\
\mathrm{~N} \\
\mathrm{~L} \\
10 \\
15 \\
10\end{array}$ & $\begin{array}{r}70 \\
15 \\
70 \\
70 \\
150 \\
70\end{array}$ & $\begin{array}{r}20 \\
100 \\
2,000 \\
500 \\
1,000 \\
300 \\
500 \\
70 \\
700 \\
700 \\
200 \\
500\end{array}$ \\
\hline \multirow{2}{*}{$\begin{array}{l}24 \\
25 \mathrm{~A}-\ldots \\
25 \mathrm{~B}-\cdots \\
25 \mathrm{C}-\ldots \\
26 \ldots \\
\ldots\end{array}$} & $\begin{array}{r}50 \\
68 \mathrm{AMm} 470 \\
470\end{array}$ & $\begin{array}{r}50 \\
20 \\
144\end{array}$ & $\begin{array}{l}\mathbf{N} \\
\mathbf{N}\end{array}$ & $\begin{array}{l}\mathrm{N} \\
\mathrm{N}\end{array}$ & $\begin{array}{r}700 \\
70\end{array}$ & $\begin{array}{r}150 \\
20\end{array}$ & $N$ & $\begin{array}{l}150 \\
100\end{array}$ & $\begin{array}{r}50 \\
5\end{array}$ & $\begin{array}{r}300 \\
30\end{array}$ & $\begin{array}{l}700 \\
200\end{array}$ \\
\hline & $\underset{51}{68 \mathrm{AGk151A}}$ & $\begin{array}{r}3 \\
150\end{array}$ & $\begin{array}{r}300 \\
\mathrm{~N}\end{array}$ & $\begin{array}{l}\mathbf{N} \\
\mathbf{N}\end{array}$ & $\begin{array}{c}300 \\
* \mathrm{G}(2,000)\end{array}$ & $\begin{array}{r}300 \\
\mathrm{~L}\end{array}$ & $\begin{array}{l}\mathbf{N} \\
\mathbf{N}\end{array}$ & $\begin{array}{r}50 \\
100\end{array}$ & $\begin{array}{l}30 \\
10\end{array}$ & $\begin{array}{l}150 \\
200\end{array}$ & $\begin{array}{r}100 \\
1,500\end{array}$ \\
\hline 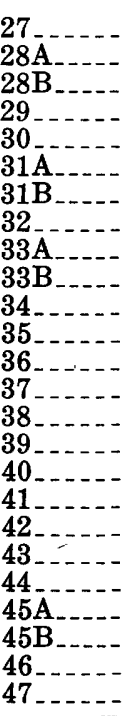 & $\begin{array}{c}\text { 68AMm215B } \\
\text { 68AEr127A } \\
127 \mathrm{~B} \\
68 \mathrm{AGk} 144 \\
143 \\
68 \mathrm{AMm} 214 \mathrm{~A} \\
214 \mathrm{C} \\
68 \mathrm{AGk} 47 \\
45 \\
68 \mathrm{AHd} 227 \\
226 \\
\text { 68AMm221A } \\
228 \\
227 \\
68 \mathrm{AHd} 56 \\
61 \\
63 \\
244 \\
65 \\
67 \\
73 \\
74 \\
75 \\
68 \mathrm{AMm} 69 \\
368\end{array}$ & $\begin{array}{r}200 \\
\mathrm{~L} \\
1 \\
7 \\
1 \\
3 \\
300 \\
\mathrm{~L} \\
\mathrm{~N} \\
\mathrm{~L} \\
150 \\
3 \\
\mathrm{~L} \\
\mathrm{~L} \\
\mathrm{~N} \\
\mathrm{~N} \\
7 \\
\mathrm{~N} \\
.5 \\
7 \\
\mathrm{~L} \\
\mathrm{~L} \\
5 \\
7 \\
3\end{array}$ & $\begin{array}{r}\mathrm{N} \\
\mathrm{L} \\
{ }^{*} \mathrm{G}(10,000) \\
\mathrm{N} \\
\mathrm{N} \\
\mathrm{N} \\
5,000 \\
\mathrm{~N} \\
\mathrm{~N} \\
\mathrm{~L} \\
\mathrm{~L} \\
\mathrm{~N} \\
\mathrm{~L} \\
3,000 \\
\mathrm{~N} \\
\mathrm{~N} \\
\mathrm{~N} \\
\mathrm{G}(10,000) \\
{ }^{*} \mathrm{G}(10,000) \\
200 \\
1,000 \\
1,500 \\
500 \\
700 \\
1,500\end{array}$ & $\begin{array}{l}\mathrm{N} \\
\mathrm{N} \\
.2 \\
\mathrm{~N} \\
\mathrm{~N} \\
\mathrm{~N} \\
\mathrm{~N} \\
\mathrm{~N} \\
\mathrm{~N} \\
\mathrm{~N} \\
\mathrm{~N} \\
\mathrm{~N} \\
\mathrm{~N} \\
1 \\
\mathrm{~N} \\
\mathrm{~N} \\
\mathrm{~N} \\
.2 \\
.7 \\
\mathrm{~N} \\
\mathrm{~N} \\
.04 \\
\mathrm{~N} \\
\mathrm{~N} \\
\mathrm{~N}\end{array}$ & $\begin{array}{c}{ }^{*} \mathrm{G}(2,000) \\
2,000 \\
*^{*} \mathrm{G}(2,000) \\
\mathrm{G}(2,000) \\
50 \\
70 \\
{ }^{*} \mathrm{G}(2,000) \\
500 \\
500 \\
200 \\
1,000 \\
70 \\
2,000 \\
{ }^{*} \mathrm{G}(2,000) \\
\mathrm{G}(2,000) \\
{ }^{*} \mathrm{G}(2,000) \\
500 \\
2,000 \\
\mathrm{G}(2,000) \\
700 \\
700 \\
1,500 \\
70 \\
{ }^{*} \mathrm{G}(2,000) \\
{ }^{*} \mathrm{G}(2,000)\end{array}$ & $\begin{array}{r}50 \\
\mathrm{~L} \\
300 \\
300 \\
500 \\
50 \\
\mathrm{~L} \\
1,000 \\
700 \\
300 \\
100 \\
5,000 \\
700 \\
150 \\
150 \\
\mathrm{~L} \\
300 \\
700 \\
200 \\
300 \\
300 \\
300 \\
300 \\
70 \\
100\end{array}$ & $\begin{array}{r}300 \\
\mathrm{~L} \\
300 \\
10 \\
\mathrm{~L} \\
\mathrm{~N} \\
\mathrm{~N} \\
\mathrm{~N} \\
\mathrm{~N} \\
\mathrm{~N} \\
\mathrm{~N} \\
\mathrm{~N} \\
\mathrm{~N} \\
20 \\
\mathrm{~N} \\
\mathrm{~N} \\
\mathrm{~N} \\
\mathrm{~N} \\
20 \\
\mathrm{~N} \\
\mathrm{~N} \\
\mathrm{~N} \\
\mathrm{~N} \\
\mathrm{~N} \\
\mathrm{~L}\end{array}$ & $\begin{array}{r}G(500) \\
\mathbf{N} \\
\mathbf{N} \\
\mathbf{N} \\
\mathbf{N} \\
\mathbf{N} \\
\mathrm{G}(500) \\
\mathbf{N} \\
\mathbf{N} \\
\mathbf{N} \\
* \mathrm{G}(500) \\
500 \\
\mathbf{N} \\
\mathbf{N} \\
\mathbf{N} \\
\mathbf{N} \\
\mathbf{N} \\
\mathbf{N} \\
\mathbf{N} \\
\mathbf{N} \\
\mathbf{N} \\
\mathbf{N} \\
\mathbf{N} \\
\mathbf{N} \\
\mathbf{N}\end{array}$ & $\begin{array}{c}100 \\
70 \\
2,000 \\
7 \\
20 \\
10 \\
20 \\
10 \\
50 \\
20 \\
150 \\
5 \\
15 \\
30 \\
150 \\
50 \\
150 \\
150 \\
150 \\
150 \\
70 \\
70 \\
15 \\
50 \\
20\end{array}$ & $\begin{array}{r}150 \\
300 \\
15 \\
150 \\
200 \\
50 \\
70 \\
100 \\
700 \\
150 \\
150 \\
7 \\
150 \\
300 \\
700 \\
70 \\
700 \\
500 \\
70 \\
700 \\
700 \\
700 \\
3,000 \\
200 \\
15\end{array}$ & $\begin{array}{r}200 \\
150 \\
500 \\
150 \\
150 \\
70 \\
200 \\
70 \\
100 \\
150 \\
500 \\
500 \\
500 \\
300 \\
500 \\
700 \\
500 \\
300 \\
300 \\
500 \\
200 \\
300 \\
70 \\
1,000 \\
300\end{array}$ \\
\hline Limits of & letermination & 0.5 & 200 & 0.02 & 10 & 50 & 10 & 50 & 10 & 10 & 10 \\
\hline \multicolumn{2}{|c|}{$\begin{array}{l}\text { Bedrock values considered } \\
\text { anomalous in this } \\
\text { report_. }\end{array}$} & 0.5 & L & 0.04 & 50 &, 000 & 10 & $\mathrm{~L}$ & 150 & 300 & 200 \\
\hline
\end{tabular}




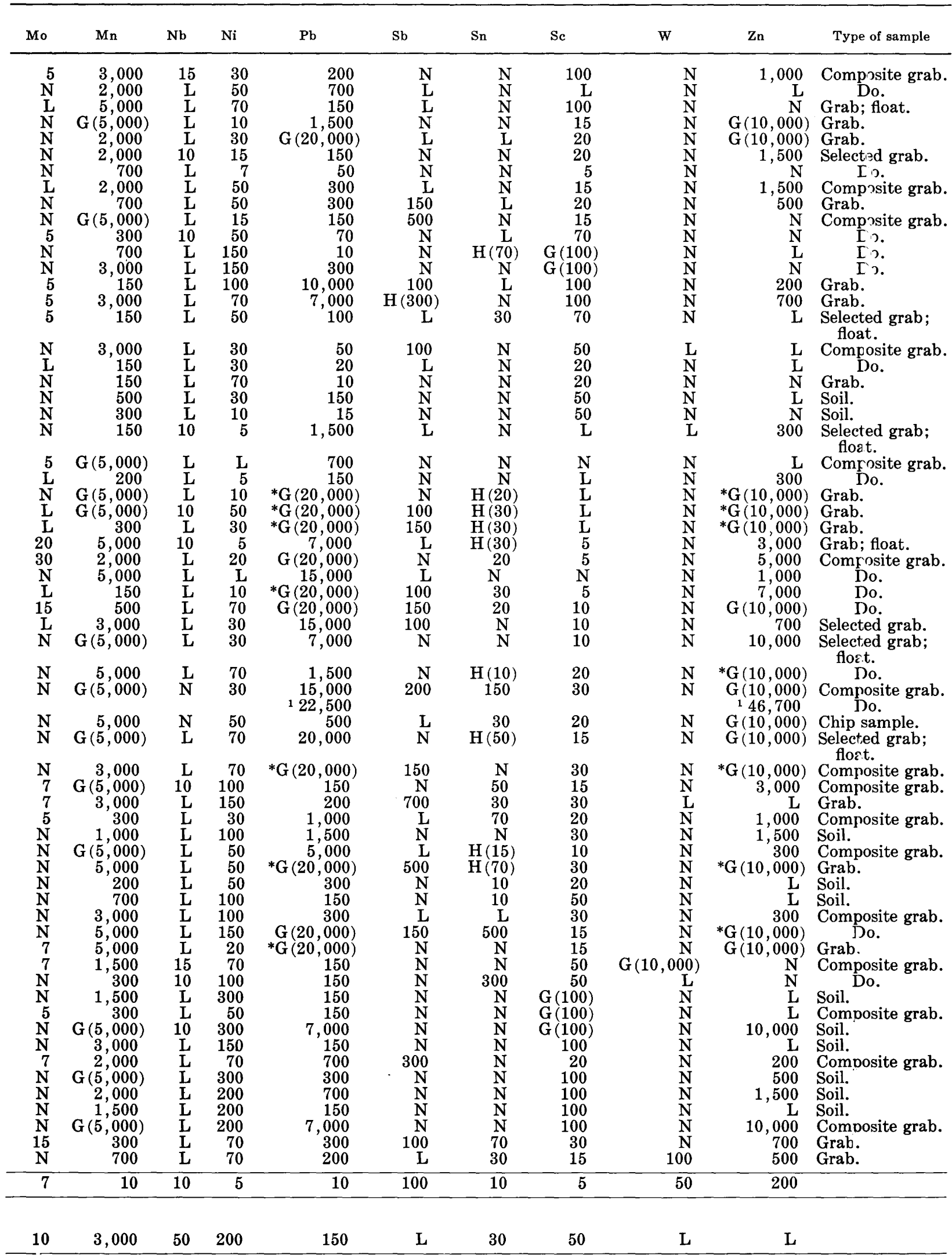


TABLE 1.-Analyses of bedrock and soil samples from Quartz Creek area-Continued

Sample

1.... Gossan in altered andesite.

2A

2B... Float; arsenopyrite and quartz.

3B. Talus; quartz vein with sphalerite.

4,5....... Altered andesite.

6.... Pyrite-bearing calcite vein.

7... Calcite veinlet cutting andesite; minor galena.

Pyrite-tourmaline-carbonate rock in 100-yard-long

Pyrite-tourmalined zone.
altered

9, 10A _.... Pyrite-tourmaline veinlets 1 inch thick in altered andesite.

10B....... Talus over 300 yards along creek; sulfide-bearing tourmaline-rich rock.

$11,12 \ldots \ldots$ Sulfide-bearing tourmaline-quartz rock.

13.

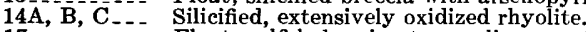

17. ..... Float; sulfide-bearing tourmaline-quartz rock.

$18 \mathrm{~A} . . . .-2 y r i t e-c a l c i t e$ vein 1 foot thick cutting altered finegrained felsic intrusive.

18B . . . . . Fine-grained felsic intrusive; altered.

18C...... Talus; sphalerite-galena-calcite vein; angular blocks up to 1 foot long.

19A_..... Talus; galena-bearing gossan.

19B ...... Talus; quartz-pyrite-arsenopyrite vein.

20A

$20 \mathrm{~B}, \mathrm{C} . . .-$ Float; sulfide-bearing gossan.
Sample

21A, B ..... Gossan with visible galena; several gossans up to 4 feet wide in quartz monzonite.

$22 \ldots . . . . .6$ Galena-bearing calcite vein 1 foot thick.

$23,24 . . .5$ Float; large boulders up to 1 foot in diameter; quartzcarbonate-sulfide rock.

25A _.... Galena-bearing calcite vein 18 inches thick.

25B...... Sulfide-carbonate-quartz rock.

26. - - Float; quartz-carbonate-sulfide rock.

27... Sulfide-bearing oxidized carbonate in altered andesite.

$28 \mathrm{~A}, \mathrm{~B}-\ldots-1$ Float, talus(?); pyrite-bearing quartz.

28B...... Talus; altered andesite containing arsenopyrite, realgar, and orpiment. 29. Sample from over 200- by 200-foot area of gossan and

31A ...... Oxidized carbonate-rich gossan in altered andesite.

31B...... Galena-bearing gossan.

33B...... Oxidized rubble in frost boil.

$34 \ldots . . . . .6$ Galena-sphalerite-pyrite-quartz veins in altered andesite.

Talus; disseminated galena in oxidized carbonate-quartz

3alus; disse

36 .......... Talus; disseminated pyrite and scheelite in quartz.

37..... Gossan along quartz monzonite-andesite contact

39-1-- Gossan along quartz monzonite-andes

$\begin{array}{ll}39 & \text { Oxidized quartz-tourmaline } r \\ 42 & \text { Oxidized rubble in frost boil. }\end{array}$

$45 \mathrm{~B} . . . . .-$ Talus(?); disseminated galena in oxidized quartz-

carbonate rock.

46-1...- Oxidized pyrite-tourmaline vein.

$47 \ldots-\ldots$ Oxidized breccia.

\section{TABLE 2.-Analyses of bedrock and soil samples from the Upper Peace River area}

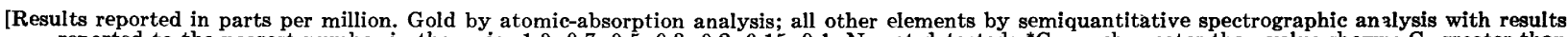
reported to the nearest number in the series $1.0,0.7,0.5,0.3,0.2,0.15,0.1$. N, not detected; ${ }^{*} \mathrm{G}$, much greater than value shown; $\mathrm{G}$, greater than value shown; $\mathrm{L}$, present but below level of determination. Sample localities are shown in fig. 7]

\begin{tabular}{|c|c|c|c|c|c|c|c|c|c|c|c|c|}
\hline $\begin{array}{l}\text { Sample } \\
\text { locality }\end{array}$ & $\begin{array}{l}\text { Field } \\
\text { No. }\end{array}$ & $\mathrm{Ag}$ & $\mathrm{Au}$ & B & $\mathbf{B i}$ & $\mathrm{Cu}$ & Mo & $\mathbf{P b}$ & Sn & W & Zn & Remarks \\
\hline 1 & 68AHd99 & $\mathrm{N}$ & 0.04 & 30 & $\mathbf{N}$ & 200 & $\mathbf{N}$ & 30 & $\mathbf{N}$ & $\mathrm{N}$ & $\mathbf{N}$ & $\begin{array}{l}\text { Altered andesite; con posite grab } \\
\text { sample. }\end{array}$ \\
\hline $2 \ldots+\ldots$ & 103 & 5 & $\mathbf{N}$ & 15 & ${ }^{*} \mathrm{G}(1,000)$ & 300 & 150 & 300 & $\mathbf{L}$ & $\mathbf{N}$ & $\mathbf{N}$ & $\begin{array}{l}\text { sample. } \\
\text { Pyritiferous oxidized syenite; com- }\end{array}$ \\
\hline 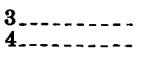 & $\begin{array}{l}104 \\
189\end{array}$ & $\begin{array}{r}150 \\
1\end{array}$ & $\stackrel{.04}{N}$ & $\begin{array}{l}20 \\
10\end{array}$ & $\begin{array}{r}* G(1,000) \\
300\end{array}$ & $\begin{array}{l}700 \\
200\end{array}$ & $\begin{array}{r}30 \\
150\end{array}$ & $\begin{array}{r}3,000 \\
150\end{array}$ & $\begin{array}{r}N \\
10\end{array}$ & $\mathbf{N}$ & $\stackrel{\mathbf{N}}{\mathbf{N}}$ & $\begin{array}{l}\text { Do. } \\
\text { Oxidized syenite witk pyritiferous } \\
\text { quartz veinlets; composite grab }\end{array}$ \\
\hline $5 \ldots \ldots$ & $68 \mathrm{AMm} 361 \mathrm{G}$ & 1 & $\mathbf{N}$ & 10 & ${ }^{*} \mathrm{G}(1,000)$ & 300 & 1,500 & 150 & $\mathbf{L}$ & $\mathbf{N}$ & $\mathbf{L}$ & Pyritiferous quartz in oxidized syenite; \\
\hline $6 \ldots$ & 68AHd105 & 1.5 & $\mathrm{~N}$ & 30 & 300 & 500 & $\mathrm{G}(2,000)$ & 300 & $\mathbf{N}$ & $\mathbf{N}$ & $\mathbf{N}$ & Oxidized syenite(?); composite grab \\
\hline $7 \ldots \ldots$ & 186 & 1 & $\mathbf{N}$ & 15 & 10 & 200 & 1,000 & 150 & 15 & $\mathbf{N}$ & $\mathbf{N}$ & $\begin{array}{l}\text { Pyritiferous quartz viins in oxidized } \\
\text { syenite; composite grab sample. }\end{array}$ \\
\hline 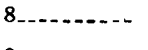 & 185 & 1.5 & $\mathbf{N}$ & 10 & 70 & 200 & 200 & 150 & 20 & $\mathbf{N}$ & $\mathbf{N}$ & $\begin{array}{l}\text { Pyritiferous oxidized syenite; com- } \\
\text { posite grab sample. }\end{array}$ \\
\hline 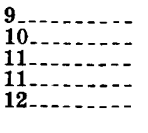 & $\begin{array}{r}184 \\
68 \mathrm{AMm} 361 \mathrm{C} \\
361 \mathrm{~A} \\
361 \mathrm{~B} \\
473\end{array}$ & $\begin{array}{r}.7 \\
\mathbf{L} \\
1.5 \\
7 \\
\mathbf{L}\end{array}$ & $\begin{array}{l}\mathbf{N} \\
\mathbf{N} \\
\mathbf{N} \\
\mathbf{N} \\
\mathbf{N}\end{array}$ & $\begin{array}{r}\mathbf{3 0} \\
20 \\
\mathrm{~L} \\
\mathrm{~L} \\
\mathbf{3 0}\end{array}$ & $\begin{array}{r}10 \\
150 \\
15 \\
20 \\
15\end{array}$ & $\begin{array}{l}100 \\
150 \\
300 \\
200 \\
300\end{array}$ & $\begin{array}{r}30 \\
15 \\
200 \\
100 \\
30\end{array}$ & $\begin{array}{r}70 \\
20 \\
20 \\
20 \\
100\end{array}$ & $\begin{array}{r}10 \\
\mathbf{L} \\
\mathbf{N} \\
\mathbf{3 0} \\
\mathbf{1 0}\end{array}$ & $\begin{array}{l}\mathbf{L} \\
\mathbf{N} \\
\mathbf{N} \\
\mathbf{N} \\
\mathbf{N}\end{array}$ & $\begin{array}{l}\mathbf{N} \\
\mathbf{N} \\
\mathbf{N} \\
\mathbf{N} \\
\mathbf{N}\end{array}$ & $\begin{array}{l}\text { posice grad sample. } \\
\text { Do. } \\
\text { Do. } \\
\text { Do. } \\
\text { Do. } \\
\text { Oxidized fine-grained syenite; com- } \\
\text { posite grab sample. }\end{array}$ \\
\hline 13 & $\begin{array}{l}\text { 68AGk160 } \\
68 \mathrm{AMm362}\end{array}$ & $\stackrel{3}{\mathrm{~L}}$ & $\stackrel{\mathbf{N}}{\mathbf{N}}$ & $\begin{array}{r}100 \\
20\end{array}$ & $\begin{array}{l}20 \\
30\end{array}$ & $\begin{array}{r}20 \\
150\end{array}$ & $\begin{array}{l}70 \\
\mathbf{3 0}\end{array}$ & $\begin{array}{l}150 \\
150\end{array}$ & $\underset{15}{\mathbf{L}}$ & $\underset{\mathbf{L}}{\mathbf{N}}$ & $\stackrel{\mathbf{N}}{\mathbf{N}}$ & $\begin{array}{l}\text { Oxidized syenite; sele ?ted grab sample. } \\
\text { Pyritiferous quartz in syenite; com- } \\
\text { posite grab sample. }\end{array}$ \\
\hline 15 & $68 \mathrm{AGk155}$ & 7 & $\mathrm{~N}$ & 200 & 20 & 150 & 15 & $\mathbf{3 0 0}$ & $\mathbf{L}$ & $\mathbf{3 0}$ & $\mathbf{L}$ & $\begin{array}{l}\text { Oxidized fluorite-bearing pyritiferous } \\
\text { syenite; selected grab sample. }\end{array}$ \\
\hline $\begin{array}{l}16 \ldots \ldots \\
17 \ldots \ldots \\
18 \ldots \ldots \\
19 \\
20 \ldots \ldots \\
21 \\
22\end{array}$ & $\begin{array}{l}63 \\
154 \\
155 \\
156 \\
158 \\
159 \\
160\end{array}$ & $\begin{array}{l}\mathbf{N} \\
\mathbf{N} \\
\mathbf{1} \\
\mathbf{N} \\
\mathbf{N} \\
\mathbf{N} \\
15\end{array}$ & $\begin{array}{l}\mathbf{N} \\
\mathbf{N} \\
\mathbf{N} \\
\mathbf{N} \\
\mathbf{N} \\
\mathbf{N} \\
\mathbf{N}\end{array}$ & $\begin{array}{r}\mathbf{7 0} \\
\mathbf{7 0} \\
\mathbf{N} \\
\mathbf{3 0} \\
\mathbf{7 0} \\
\mathbf{3 0} \\
\mathbf{2 0 0}\end{array}$ & $\begin{array}{l}\mathbf{N} \\
\mathbf{L} \\
15 \\
\mathbf{N} \\
\mathbf{N} \\
15 \\
70\end{array}$ & $\begin{array}{r}50 \\
30 \\
500 \\
200 \\
150 \\
200 \\
\mathbf{2 0 0}\end{array}$ & $\begin{array}{l}\mathrm{N} \\
\mathbf{1 5} \\
70 \\
50 \\
\mathbf{3 0} \\
\mathbf{3 0} \\
\mathbf{3 0}\end{array}$ & $\begin{array}{r}100 \\
70 \\
300 \\
200 \\
150 \\
150 \\
1,000\end{array}$ & $\begin{array}{l}\mathbf{N} \\
\mathbf{N} \\
\mathbf{N} \\
\mathbf{N} \\
\mathbf{N} \\
\mathbf{N} \\
\mathbf{N}\end{array}$ & $\begin{array}{l}\mathbf{N} \\
\mathbf{N} \\
\mathbf{N} \\
\mathbf{7 0} \\
\mathbf{N} \\
\mathbf{N} \\
\mathbf{N}\end{array}$ & $\begin{array}{l}\mathbf{L} \\
\mathbf{N} \\
\mathbf{N} \\
\mathbf{N} \\
\mathbf{N} \\
\mathbf{N} \\
\mathbf{N}\end{array}$ & $\begin{array}{l}\text { Soil samples. } \\
\text { Do. } \\
\text { Do. } \\
\text { Do. } \\
\text { Do. } \\
\text { Do. } \\
\text { Do. }\end{array}$ \\
\hline Limits of det & ermination.-...- & 0.5 & 0.02 & 10 & 10 & 5 & $\mathbf{5}$ & 10 & 10 & 50 & 200 & \\
\hline \multicolumn{2}{|c|}{$\begin{array}{l}\text { Bedrock values considered } \\
\text { anomalous in this report.- }\end{array}$} & 0.5 & 0.04 & 50 & 10 & 200 & 10 & 150 & $\mathbf{3 0}$ & $\mathbf{L}$ & $\mathbf{L}$ & \\
\hline
\end{tabular}


TABLE 3.-Partial analyses of stream sediment samples from the upper Peace River area

[Results are reported in parts per million. Analyses are by semiquantitative spectrographic methods with results reported to the nearest number in the series $1.0,0.7,0.5,0.3,0.2,0.15,0.1$. $\mathrm{N}$, not detected; L, present but below limit of determination. Sample localities shown in fig. 8 ]

\begin{tabular}{|c|c|c|c|c|c|c|c|c|c|c|c|}
\hline Sample locality & Field No. & Mo & $\mathrm{Cu}$ & $\mathrm{Pb}$ & $\mathrm{Ag}$ & Sample locality & Field No. & Mo & $\mathrm{Cu}$ & $\mathbf{P b}$ & $\mathrm{Ag}$ \\
\hline $\begin{array}{l}1 \\
2 \\
3 \\
3 \\
4 \\
5 \\
6\end{array}$ & $\begin{array}{c}\text { 68AHd197 } \\
\text { 68AEr193 } \\
243 \\
\text { 68AGk66 } \\
65 \\
157 \\
67 \\
69 \\
68 \\
70 \\
71 \\
\text { 68AHd204 } \\
205 \\
210 \\
211\end{array}$ & $\begin{array}{l}\mathrm{N} \\
\mathrm{N} \\
7 \\
7 \\
\mathrm{~L} \\
30 \\
10 \\
15 \\
15 \\
30 \\
30 \\
\mathrm{~N} \\
\mathrm{~N} \\
\mathrm{~N} \\
\mathrm{~N}\end{array}$ & $\begin{array}{r}50 \\
15 \\
30 \\
70 \\
30 \\
150 \\
70 \\
30 \\
30 \\
300 \\
150 \\
15 \\
100 \\
200 \\
150\end{array}$ & $\begin{array}{r}30 \\
150 \\
100 \\
100 \\
500 \\
200 \\
300 \\
300 \\
150 \\
150 \\
150 \\
100 \\
\text { L } \\
20 \\
\text { L }\end{array}$ & $\begin{array}{l}\mathrm{N} \\
\mathrm{N} \\
\mathrm{N} \\
\mathrm{L} \\
\mathrm{L} \\
\mathrm{N} \\
.7 \\
.7 \\
\mathrm{~L} \\
.5 \\
\mathrm{~L} \\
\mathrm{~N} \\
\mathrm{~N} \\
\mathrm{~N} \\
\mathrm{~N}\end{array}$ & 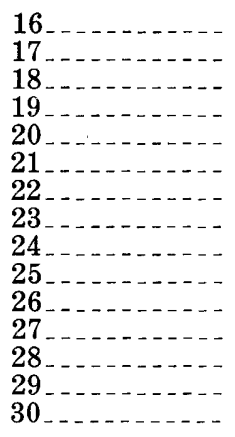 & $\begin{aligned} 68 \mathrm{AHd} 213 \\
88 \\
94 \\
95 \\
214 \\
98 \\
100 \\
196 \\
195 \\
194 \\
190 \\
106 \\
68 \mathrm{AEr} 246 \\
200 \\
201\end{aligned}$ & $\begin{array}{l}\mathrm{N} \\
\mathrm{N} \\
\mathrm{N} \\
15 \\
\mathrm{~N} \\
\mathrm{~N} \\
7 \\
\mathrm{~N} \\
\mathrm{~N} \\
\mathrm{~N} \\
\mathrm{~N} \\
\mathrm{~N} \\
\mathrm{~L} \\
7 \\
\mathrm{~N}\end{array}$ & $\begin{array}{r}300 \\
15 \\
100 \\
100 \\
30 \\
150 \\
100 \\
30 \\
70 \\
100 \\
150 \\
70 \\
10 \\
200 \\
100\end{array}$ & $\begin{array}{r}10 \\
15 \\
15 \\
100 \\
30 \\
15 \\
30 \\
70 \\
20 \\
70 \\
70 \\
70 \\
30 \\
150 \\
100\end{array}$ & $\begin{array}{l}\mathbf{N} \\
\mathbf{N} \\
\mathbf{N} \\
\mathbf{N} \\
\mathbf{N} \\
\mathbf{N} \\
\mathbf{N} \\
\mathbf{N} \\
\mathbf{N} \\
\mathbf{N} \\
\mathbf{N} \\
\mathbf{N} \\
\mathbf{N} \\
\mathbf{N} \\
\mathbf{N}\end{array}$ \\
\hline Limits of determ & 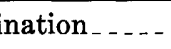 & 5 & 5 & 10 & 0.5 & Limits of deterr & lation $\ldots . . .$. & 5 & 5 & 10 & 0.5 \\
\hline
\end{tabular}

TABLE 4.-Analyses of bedrock samples from the Bear Creek prospect [Results reported in parts per million. Gold by atomic-absorption analysis; all other elements by semiquantitative spectrographic analysis with results reported to the nearest number in the series
$1.0,0.7,0.5,0.3,0.2,0.15,0.1$. N, not detected; ${ }^{*} \mathrm{G}$, much greater than value shown; $G$, greater than value shown; $L$, below limit of determination]

\begin{tabular}{|c|c|c|c|c|c|c|c|c|c|c|c|c|c|c|c|c|c|c|c|c|}
\hline Sample & Field No. & $\mathrm{Ag}$ & As & $\mathbf{A u}$ & B & $\mathrm{Ba}$ & $\mathrm{Bi}$ & $\mathrm{Cd}$ & $\mathrm{Co}$ & $\mathrm{Cr}$ & $\mathrm{Cu}$ & Mo & Mn & $\mathrm{Nb}$ & $\mathrm{Ni}$ & $\mathbf{P b}$ & $\mathrm{Sb}$ & $\mathrm{Sn}$ & Se & $\mathrm{Zn}$ \\
\hline 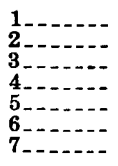 & $\begin{array}{c}\text { 68AGk95 } \\
98 \\
175 \mathrm{D} \\
175 \mathrm{E} \\
175 \mathrm{~F} \\
175 \mathrm{G} \\
175 \mathrm{H}\end{array}$ & $\begin{array}{l}1.5 \\
50 \\
30 \\
30 \\
150 \\
30 \\
150\end{array}$ & $\begin{array}{r}{ }^{*} \mathrm{G}(10,000) \\
\mathbf{2}, 000 \\
500 \\
1,000 \\
\mathbf{1}, 500 \\
\mathbf{3}, 000 \\
7,000\end{array}$ & $\begin{array}{r}3.0 \\
.8 \\
1.4 \\
1.2 \\
1.1 \\
.4 \\
.7\end{array}$ & $\begin{array}{l}\mathbf{3 0} \\
30 \\
20 \\
30 \\
20 \\
30 \\
\mathbf{3 0}\end{array}$ & $\begin{array}{r}500 \\
\mathrm{~L} \\
20 \\
150 \\
20 \\
700 \\
150\end{array}$ & $\begin{array}{c}\mathrm{L} \\
10 \\
10 \\
\mathrm{~N} \\
10 \\
\mathrm{~N} \\
\mathrm{~N}\end{array}$ & $\begin{array}{r}\mathrm{N} \\
\mathrm{L} \\
\mathrm{N} \\
150 \\
200 \\
70 \\
150\end{array}$ & $\begin{array}{l}70 \\
50 \\
15 \\
15 \\
20 \\
15 \\
10\end{array}$ & $\begin{array}{r}100 \\
100 \\
30 \\
70 \\
50 \\
70 \\
70\end{array}$ & $\begin{array}{r}50 \\
500 \\
200 \\
150 \\
1,000 \\
500 \\
500\end{array}$ & $\begin{array}{l}\mathrm{N} \\
\mathrm{N} \\
\mathrm{N} \\
5 \\
\mathbf{N} \\
7 \\
7\end{array}$ & $\begin{array}{c}2,000 \\
\mathrm{G}(5,000) \\
2,000 \\
\mathrm{G}(5,000) \\
2,000 \\
\mathrm{G}(5,000) \\
\mathrm{G}(5,000)\end{array}$ & $\begin{array}{l}10 \\
10 \\
\mathrm{~N} \\
\mathrm{~L} \\
\mathrm{~N} \\
10 \\
10\end{array}$ & $\begin{array}{l}30 \\
50 \\
30 \\
50 \\
50 \\
70 \\
30\end{array}$ & $\begin{array}{r}200 \\
20,000 \\
20,000 \\
{ }^{*} \mathrm{G}(20,000) \\
{ }^{G}(20,000) \\
{ }^{*} \mathrm{G}(20,000) \\
{ }^{*} \mathrm{G}(20,000)\end{array}$ & $\begin{array}{r}\mathrm{L} \\
3,000 \\
1,000 \\
1,000 \\
1,000 \\
\mathrm{G}(10,000) \\
*_{\mathrm{G}}(10,000)\end{array}$ & $\begin{array}{l}\mathbf{N} \\
\mathbf{N} \\
\mathbf{N} \\
\mathbf{N} \\
\mathbf{N} \\
\mathbf{N} \\
\mathbf{N}\end{array}$ & $\begin{array}{r}30 \\
50 \\
7 \\
10 \\
10 \\
15 \\
7\end{array}$ & $\begin{array}{r}1,000 \\
3,000 \\
700 \\
G(10,000) \\
G(10,000) \\
G(10,000) \\
G(10,000)\end{array}$ \\
\hline Limits of & etermination - - & 0.5 & 100 & 0.02 & 10 & 50 & 10 & 50 & 10 & 10 & 10 & 7 & 10 & 10 & 5 & 10 & 100 & 10 & 5 & 200 \\
\hline \multicolumn{2}{|c|}{$\begin{array}{l}\text { Bedrock values considered } \\
\text { anomalous in this } \\
\text { report. }\end{array}$} & 0.5 & L & 0.04 & 50 & 2,000 & 10 & L & 150 & 300 & 200 & 10 & 3,000 & 50 & 200 & 150 & $\mathbf{L}$ & 30 & 50 & L \\
\hline
\end{tabular}

\begin{tabular}{|c|c|c|c|}
\hline Sample & Description & Sample & Description \\
\hline & $\begin{array}{l}\text { Selected grab sample of oxidized andesite float; contains } 10 \text { to } 15 \text { percent sulfids. } \\
\text { Selected grab sample of andesite along } 100 \text {-yard-long altered zone in creek bank. } \\
\text { Chip sample over } 11 \text { feet of andesite in cutbank. Visible pyrite, arsenopyrite, and } \\
\text { galena in quartz-carbonate gangue. } \\
\text { Chip sample over } 18 \text { feet of oxidized andesite. }\end{array}$ & 6-1 & $\begin{array}{l}\text { Grah sample from 12-inch-thick vein of galena, pyrite, and sphalerite in quartz- } \\
\text { carbonate gangue. } \\
\text { Composite grab sample from pyrite-galena-bournonite veinlets in altered andesite. } \\
\text { Collected over } 10 \text { - by } 30 \text {-foot area. } \\
\text { Selected grab sample from 8-inch-thick pyrite-galena-quartz-carbonate vein in } \\
\text { andesite. }\end{array}$ \\
\hline
\end{tabular}


